Proc. Estonian Acad. Sci. Geol., 2005, 54, 3, 153-180

\title{
Lithology and evolution of Devonian carbonate and carbonate-cemented rocks in Estonia
}

\begin{abstract}
Anne Kleesment and Alla Shogenova
Institute of Geology at Tallinn University of Technology, Estonia pst. 7, 10143 Tallinn, Estonia; kleesmen@gi.ee

Received 7 April 2005, in revised form 3 June 2005

Abstract. The Devonian sedimentary sequence of Estonia is mainly composed of terrigenous rocks, but includes also carbonate and mixed carbonate-siliciclastic rocks. The accumulation of siliciclastic sediments has recurrently alternated with carbonate sedimentation. Carbonate rocks are best represented in the Narva Regional Stage where they are fully dolomitized. In addition to pure dolostones, dolomitic marlstones, and siliciclastic sediments, mixed carbonate-siliciclastic rocks were recorded in six studied drill cores (Ruhnu (500), Taagepera, Tartu (453), Valga (10), Võru, and Värska (6)). Mixed rocks were deposited in transitional tidal flat conditions of shallow epicontinental sea during simultaneous accumulation of carbonate and siliciclastic material. They include also terrigenous rocks cemented by dolomite during diagenesis. According to mineralogical, petrographical, and geochemical data, early diagenetic dolostones and dolomitic marlstones were deposited in the shallow nearshore tidal flat environment in the sea water saturated with $\mathrm{Mg}$, but changed in the next stages of diagenesis. Siliciclastic rocks were cemented during middle and late diagenesis by $\mathrm{Mg}$ and Mn-enriched fluids. Sometimes cement of siliciclastic and mixed rocks is represented by gypsum and late diagenetic calcite. The porosity of Devonian rocks increases with increasing clay content, and decreases with mechanical compaction, dolomitization, and carbonate cementation. The sedimentation and diagenetic history are reflected in gamma-ray logs.
\end{abstract}

Key words: Devonian, carbonate rocks, siliciclastic rocks, mixed rocks, chemical composition, diagenesis, X-ray diffractometry, porosity, gamma-ray logs.

\section{INTRODUCTION}

The Devonian sequence of Estonia is represented mainly by siliciclastic rocks (Kleesment \& Mark-Kurik 1997). Siliciclastic material accumulated in epicontinental shallow sea, alternating with carbonate sedimentation. Mixed carbonatesiliciclastic deposits formed in intertidal and open shelf settings experiencing marine transgressions and regressions. The largest influx of siliciclastic material was from the Scandinavian granite massifs (Kleesment 1997; Plink-Björklund \& Björklund 1999). Carbonate sedimentation was especially widespread during Middle Devonian Narva age, when the carbonate sequence reached a thickness 
of $70 \mathrm{~m}$. Interlayers of carbonate rocks occur also in the other parts of the Middle and Lower Devonian. As a result of the later multistage diagenetic changes, siliciclastic rocks were cemented by carbonate minerals, especially by dolomite. The lithology of Devonian carbonate and carbonate-cemented siliciclastic rocks is less investigated than that of siliciclastic rocks, thus the aim of the present work is to give a detailed overview of the corresponding study in Estonia.

The samples were collected from six drill cores (Ruhnu (500), Taagepera, Tartu (453), Valga (10), Võru, and Värska (6)) located in southern Estonia (Fig. 1). In addition to 96 samples taken from these boreholes, some samples from the Värska (2) borehole and the data of different analyses made in the laboratories of the Institute of Geology at Tallinn University of Technology (IG TUT) in the years 1970-1990 were considered. The rocks were analysed on the basis of their chemical and mineralogical composition, texture, and porosity. Thin sections made from 14 dolostones, 4 dolomitic marlstones, 12 mixed and 10 siliciclastic samples were studied. Most of the samples were from the Narva Regional Stage, but also from the Aruküla, Pärnu, and Rēzekne regional stages (Figs. 2, 3).

Natural gamma-ray (GR) logs were used for the correlation of Devonian formations and beds. Gamma-ray logs have been applied in Estonia since the 1960s for correlation purposes (Shogenova 1989). They constitute a very important source of geological information in Estonia, because GR was the only logging tool applied to study the boreholes drilled in loosely cemented rocks with a low core yield. The intervals in three of the studied boreholes (Võru, Värska (6), Taagepera) not represented by core were correlated using GR logs on the basis of the data available from neighbouring boreholes (Figs. 2, 3).

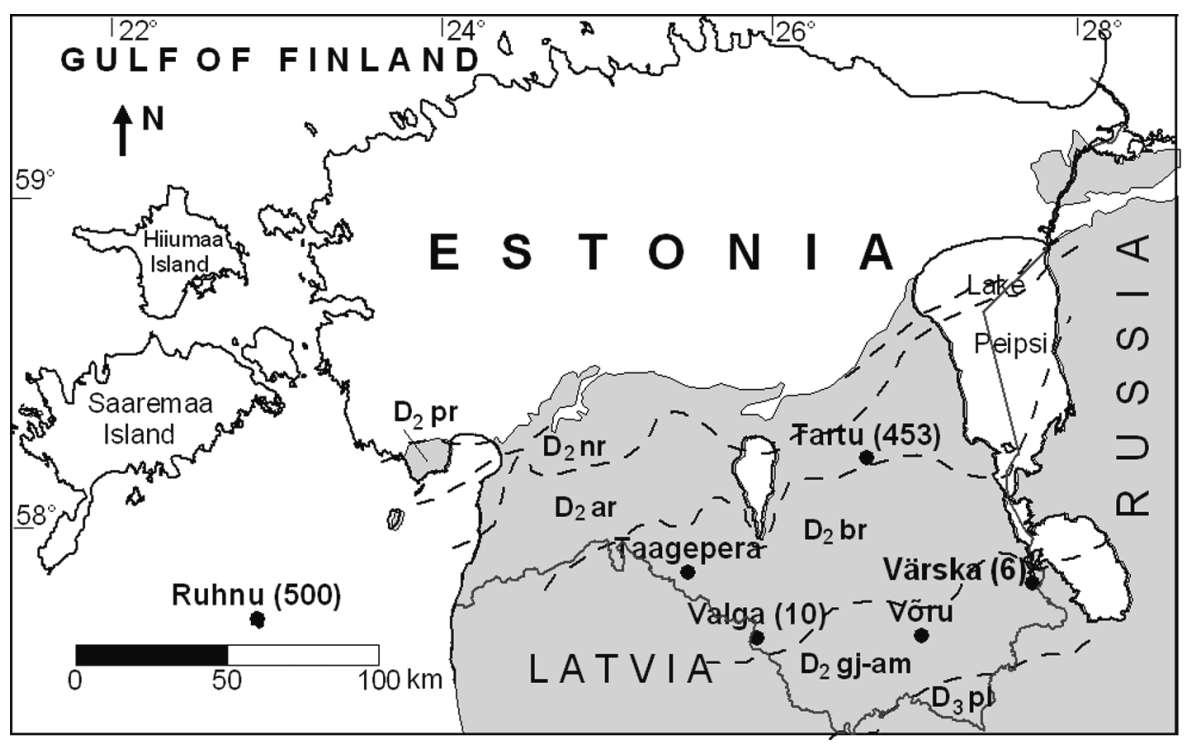

Fig. 1. Map of Estonia showing the distribution of Devonian stratigraphical units and location of the studied boreholes. $\mathrm{D}_{2}$ pr, Pärnu Stage; $\mathrm{D}_{2} \mathrm{nr}$, Narva Stage; $\mathrm{D}_{2}$ ar, Aruküla Stage; $\mathrm{D}_{2}$ br, Burtnieki Stage; $\mathrm{D}_{2}$ gj-am, Gauja and Amata stages; $\mathrm{D}_{3}$ pl, Plavinas Stage. 


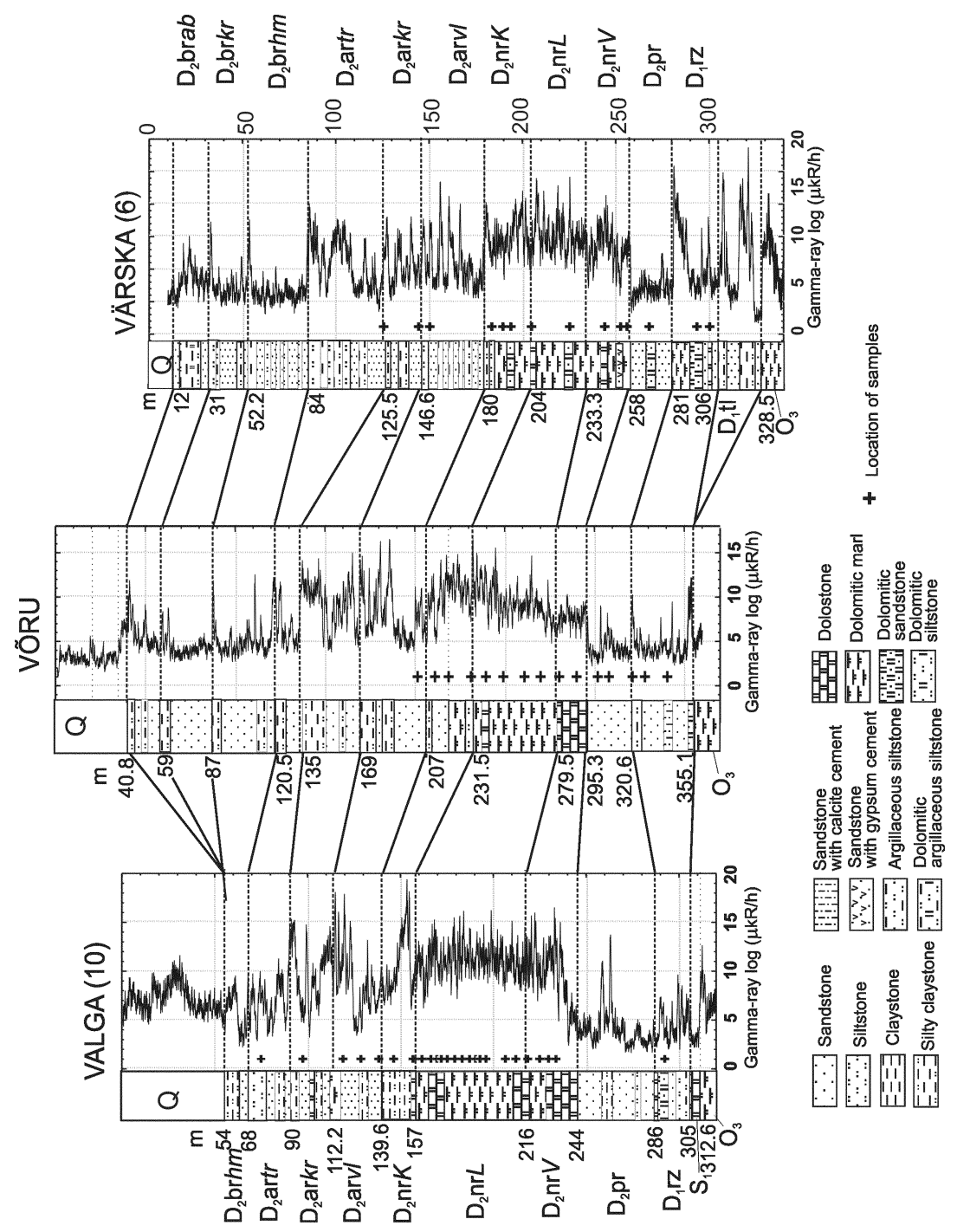

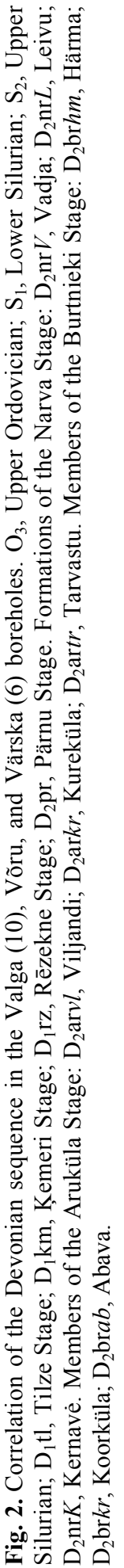




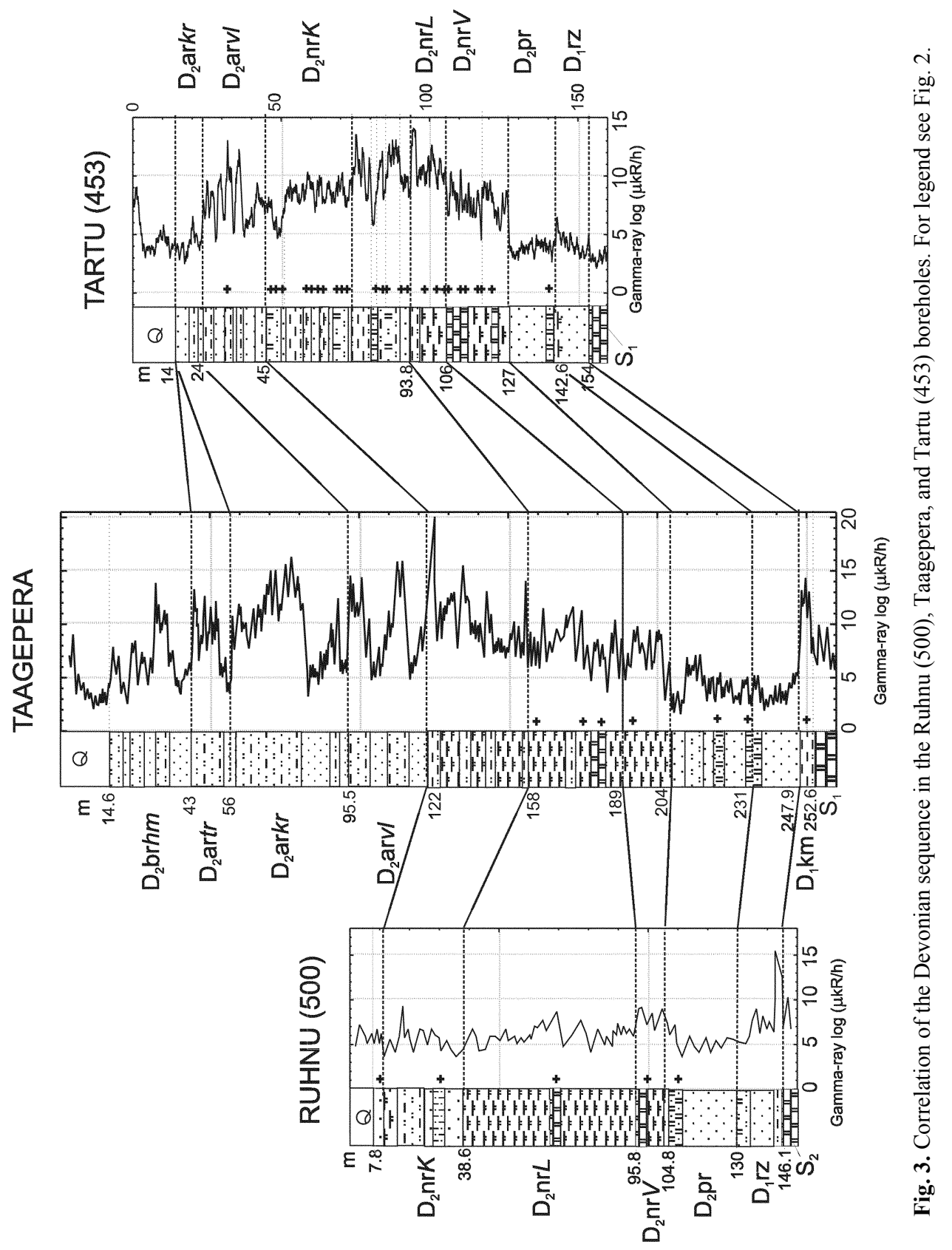


Interpretation of dolomite genesis was based on mineralogic, petrographic, and geochemical data. The Devonian sequence is an excellent source to study diagenetic alteration processes and first of all cementation of siliciclastic and carbonatesiliciclastic complexes.

\section{GEOLOGICAL BACKGROUND}

Devonian deposits lie with stratigraphical unconformity on Silurian or Ordovician rocks. In the Värska (6) and Võru cores the sequence begins with the deposits of the Lower Devonian Tilže Regional Stage $\left(D_{1} t\right)$, represented by alternating siliciclastic and argillaceous rocks. In the Taagepera core the sequence begins with a thin layer of silt- and claystones of the Kemeri Regional Stage $\left(\mathrm{D}_{1} \mathrm{~km}\right)$, overlain by a stratigraphical gap and the rocks of the Rēzekne Regional Stage $\left(D_{1} r z\right)$. In the other sections it begins with the Rēzekne Stage, which is overlain by the Middle Devonian Pärnu ( $\left.D_{2} \mathrm{pr}\right)$, Narva $\left(\mathrm{D}_{2} \mathrm{nr}\right)$, Aruküla $\left(\mathrm{D}_{2} \mathrm{ar}\right)$, and Burtnieki $\left(\mathrm{D}_{2}\right.$ br) regional stages. From the Rezzekne deposits up to the middle part of the Aruküla Stage the Devonian sequence is well represented in these boreholes (Kleesment \& Mark-Kurik 1997; Figs. 2, 3).

The Rēzekne and Pärnu stages, with a total thickness of 27-61 m, are represented mostly by weakly cemented siliciclastic rocks, dominated by grey fine- to medium-grained sandstones. The illite-chlorite cement forms about $1-5 \%$, strongly cemented varieties account for about $4-10 \%$ of the sequence. Interbeds of dolomitic marlstone, dolostone, and claystone occur in its topmost part. Interlayers of carbonate-cemented siliciclastic rocks are present near the carbonate rocks in the basal part (1-3 m) of the Rèzekne Stage (Formation), lying on the carbonate complexes of the Ordovician or Silurian, and in the upper part of the Pärnu Stage (Formation), covered by dolomitized rocks of the Narva Stage. The carbonatecemented siliciclastic rocks occur also in the topmost part of the Rēzekne Formation and in the basal part of the Pärnu Formation, in the sections where the upper part of the Rēzekne Formation is represented by dolomitic marl (Kleesment $\&$ Mark-Kurik 1997). The cement content of siliciclastic rocks is up to $40 \%$.

The Narva Stage is represented by the successive Vadja $\left(\mathrm{D}_{2} \mathrm{nr} V\right)$, Leivu $\left(\mathrm{D}_{2} \mathrm{nr} L\right)$, and Kernave $\left(\mathrm{D}_{2} \mathrm{nrK}\right)$ formations (Kleesment \& Mark-Kurik 1997; Kleesment \& Valiukevičius 1998). The lower, Vadja Formation, 9-28 m thick, is characterized by a thin-bedded complex of alternating grey dolomitic marl, light grey and yellowish-grey dolostone, and dark grey claystone. The dolostone is often cracked, cavernous and includes vugs and stretches (fractures) filled with crystalline dolomite. Desiccation cracks and chalcedony have been found. The layer of sedimentary breccia widespread in the basal part of the Vadja Formation (Kleesment \& Kurik 1997) is well represented in the Ruhnu (500), Võru and Tartu (453) drill cores, but is not quite clearly observed in the Värska (6) and Valga (10) cores, and is absent in the Taagepera borehole (Kleesment 2001). 
The thickness of the laterally variable Leivu Formation $\left(\mathrm{D}_{2} \mathrm{nr} L\right)$ changes from $12.2 \mathrm{~m}$ in the Tartu core up to $57.2 \mathrm{~m}$ in the Ruhnu (500) core. Dolomitic marlstone with varying clay content, including interbeds of dolostone and claystone, dominate in the sequence and few interlayers of grey siltstone occur in its upper part. Dolomitic marlstone is mostly grey, whereas mottled varieties are present in the upper part of the formation.

The Kernave Formation $\left(\mathrm{D}_{2} \mathrm{nrK}\right)$ is about $17.4-48.8 \mathrm{~m}$ thick. It is represented by a horizontally thinly interbedded sequence of brownish-red and grey, weakly illite-chlorite- and strongly dolomite-cemented very fine to fine-grained sandstone including interlayers of grey and reddish-brown silt- and claystone and mottled dolomitic marlstone. The rock sequence is horizontal or lenticular medium- to thin-bedded. The content of dolomitic cement in siliciclastic rocks is about $20-50 \%$.

The thickness of the Viljandi Member $\left(\mathrm{D}_{2} \mathrm{ar} v l\right)$ of the Aruküla Stage is 27.4 $38.0 \mathrm{~m}$. The member is mainly represented by thin- to medium-bedded reddishbrown, fine-grained and very fine-grained sandstone, containing interbeds of varicoloured claystone and dolomitic marlstone, and grey siltstone. Siliciclastic rocks with illite cement prevail. The content of dolomite-cemented siliciclastic rocks is about $5-30 \%$.

The middle, Kureküla Member $\left(\mathrm{D}_{2}\right.$ arkr $)$ and the upper, Tarvastu Member $\left(\mathrm{D}_{2}\right.$ artr $)$ of the Aruküla Stage were recognized in the Värska (6) and Valga (10) cores and, according to the GR logs, were interpreted in the Taagepera and Vorru cores (Figs. 2, 3). The thickness of the Kureküla Member increases from east to west (from $21.1 \mathrm{~m}$ in the Värska (6) core to $39.5 \mathrm{~m}$ in the Taagepera core) and of the Tarvastu Member from west to east (from $13 \mathrm{~m}$ in the Taagepera core to $41.5 \mathrm{~m}$ in the Värska (6) core). These units are represented by the intercalating sequence of reddish-brown, yellowish-red and pinkish-red sandstone, variegated siltstones and reddish-brown silty claystones. The proportion of dolomite-cemented siliciclastic rocks is about $5-30 \%$.

The Burtnieki Stage is complete in the Värska (6) and Vorru cores, and is represented only by its lower unit (Härma Member, $\mathrm{D}_{2} \mathrm{brhm}$ ) in the Valga (10) and Taagepera cores. The thickness of the unit reaches $79.7 \mathrm{~m}$ in the Vorru core. The succession of the Burtnieki Stage consists mainly of light greyish-brown, yellowish and pinkish, weakly to medium-cemented sandstone, interbedding with varicoloured claystone and greenish-grey siltstone. Dolomite-cemented varieties are extremely rare. Sandstone contains mainly clayey cement (2-5\%), including besides dominating illite admixture up to $40 \%$ kaolinite.

\section{ANALYTICAL METHODS}

Geophysical borehole logging was performed by the Geological Survey of Estonia in the 1960s-1980s. Gamma ray logs were measured using stations SK-1-69 
or AEKS-1500 and radiometers RSKM-2 (crystals CsY (Tl) $30 \mathrm{~mm} \times 40 \mathrm{~mm}$ in size) or RSKU (crystals NaY(Tl) $25 \mathrm{~mm} \times 76 \mathrm{~mm}$ in size). The logging rate (v) was $300-400 \mathrm{~m} / \mathrm{h}$. Gamma rays were registered on a vertical scale of $1: 200$. The integration time $(\tau)$ was 1.5 and $3.0 \mathrm{~s}$. The measurements were recalculated into $\mu \mathrm{kR} / \mathrm{h}$, where $1 \mu \mathrm{kR} / \mathrm{h}=7.166 \times 10^{-14} \mathrm{~A} / \mathrm{kg}$.

The chemical composition of the rocks was determined by X-ray fluorescence analysis in the All-Russian Geological Institute, St. Petersburg. $\mathrm{Na}_{2} \mathrm{O}$ and $\mathrm{P}_{2} \mathrm{O}_{5}$ were measured with the detection limit of $500 \mathrm{ppm}$, which was not sufficient for the studied rocks and in many samples these elements were not detected. $\mathrm{MnO}$ was measured with the $50 \mathrm{ppm}$ detection limit, and was under that level only in one sandstone sample. For statistical and correlation purposes, half of the detection limit was applied to the samples where these elements were not detected. Detection limits for other chemical elements were sufficient for the studied rocks. Wet chemical analysis of insoluble residue (IR) and $\mathrm{FeO}$ contents were made in the IG TUT.

The displacement of the $d_{104}$ peak relative to a standard was determined by the XRD analysis of the dolomitized rocks (IG TUT). X-ray diffractometry measurements were carried out on a diffractometer HZG4, using Fe-filtered Co radiation. The rock powder was mixed in a mortar with $\mathrm{Si}$ in relation $8: 2$, some drops of ethanol were added, and the mixture was evenly spread on a glass slide. The measured angular range $32-38^{\circ} 2 \theta$ reveals the 104 reflection of dolomite and calcite and 111 reflection of Si. The positions of reflections were calculated as weighted average. The instrumental shift was corrected according to the $\mathrm{Si}$ reflection (3.1355). The precision of the measurement of $d_{104}$ is $\pm 0.0005 \AA$ (Teedumäe et al. 1999, 2001, 2003, 2004).

The molar concentration of $\mathrm{CaCO}_{3}\left(m_{\mathrm{Ca}}\right)$ in dolomite (Table 1) was calculated by measuring the displacement of the $d_{104}$ peak relative to a standard (Lippmann 1973). The formula

$$
m_{\mathrm{Ca}}=\left(d_{104}-2.884\right) / 0.003+50
$$

expresses the linear dependence of the $d_{104}$ reflection with respect to the fix-point of ideal stoichiometric dolomite, the value of which $(2.884 \AA)$ was calculated (Teedumäe et al. 1999) on the basis of the composition of two standards, Es-4 (Estonia) and SI-1 (former USSR). Such calculation is possible only for non-ferroan dolomites not bearing ankerite ( $<2 \mathrm{~mol} \% \mathrm{FeCO}_{3}$ by Goldsmith \& Graf 1958).

Rock porosity was measured at room temperature and pressure in the Laboratory of the Geological Survey of Finland on samples with a size of 50$200 \mathrm{~cm}^{3}$ (54 samples) (Jõeleht \& Kukkonen 2002) and in the Petrophysical Laboratory of the Research Institute of the Earth's Crust of St. Petersburg University on cubes of $24 \mathrm{~mm}$ side (40 samples) (Priyatkin \& Polyakov 1983; Shogenova 1998). 
Table 1. Composition and properties of Devonian rocks*

\begin{tabular}{|c|c|c|c|c|}
\hline \multirow{3}{*}{ Studied parameter } & \multicolumn{4}{|c|}{ Rock type } \\
\hline & Dolostones & $\begin{array}{l}\text { Dolomitic } \\
\text { marlstones }\end{array}$ & \begin{tabular}{|l|} 
Mixed carbonate- \\
siliciclastic rocks
\end{tabular} & $\begin{array}{c}\text { Siliciclastic } \\
\text { rocks }\end{array}$ \\
\hline & \multicolumn{4}{|c|}{$\frac{\text { Min-Max/Avg }}{\text { Std. Dev. }(N)}$} \\
\hline Porosity, \% & $\frac{2.5-21.7 / 10.8}{4.3(25)}$ & $\frac{8.7-28.8 / 16}{4.9(17)}$ & $\frac{3.6-27.3 / 12.9}{6.4(20)}$ & $\frac{13-37.1 / 23.2}{5.8(25)}$ \\
\hline Insoluble residue, $\%$ & $\frac{2.7-23.5 / 14}{5.8(25)}$ & $\frac{25.9-49 / 38.1}{7.36(17)}$ & $\frac{51-69.2 / 59.6}{5.4(21)}$ & $\frac{70.2-95 / 80.2}{7.5(27)}$ \\
\hline $\mathrm{MgO}, \%$ & $\frac{15.2-19.7 / 17.4}{1.1(25)}$ & $\frac{10.3-15.6 / 13.2}{1.6(17)}$ & $\frac{6-10.2 / 8.1}{1.2(21)}$ & $\frac{\leq 0.05-6.6 / 3.7}{1.7(27)}$ \\
\hline $\mathrm{CaO}, \%$ & $\frac{22-30.2 / 25.3}{2.1(25)}$ & $\frac{13.3-21.7 / 17.7}{2.5(17)}$ & $\frac{8.4-16.1 / 11.7}{2.3(21)}$ & $\frac{0.15-10.8 / 5.2}{3.2(27)}$ \\
\hline $\mathrm{SiO}, \%$ & $\frac{0.74-17.5 / 12.6}{4.4(17)}$ & $\frac{19.1-44.3 / 28}{6.9(17)}$ & $\frac{39-66.5 / 51.4}{8.3(21)}$ & $\frac{53.6-89 / 67}{9.5(27)}$ \\
\hline $\mathrm{Al}_{2} \mathrm{O}_{3}, \%$ & $\frac{2.4-5.7 / 4}{1(17)}$ & $\frac{3.5-12 / 7.1}{1.1(17)}$ & $\frac{1.1-13.1 / 5.9}{3.6(21)}$ & $\frac{3-16.6 / 8.3}{3.1(27)}$ \\
\hline $\mathrm{K}_{2} \mathrm{O}, \%$ & $\frac{0.2-1.9 / 1.3}{0.43(17)}$ & $\frac{1.8-3.9 / 2.6}{0.5(17)}$ & $\frac{0.9-4.9 / 3.1}{1.4(21)}$ & $\frac{2-6.5 / 4.7}{1.2(27)}$ \\
\hline $\mathrm{TiO}_{2}, \%$ & $\frac{\leq 0.005-0.26 / 0.14}{0.06(17)}$ & $\frac{0.18-0.47 / 0.33}{0.07(17)}$ & $\frac{<0.01-0.58 / 0.29}{0.19(21)}$ & $\frac{0.18-0.99 / 0.49}{0.2(27)}$ \\
\hline $\mathrm{Fe}_{2} \mathrm{O}_{3}$ total, $\%$ & $\frac{0.6-2.6 / 1.6}{0.5(17)}$ & $\frac{0.9-5.5 / 2.8}{1.1(17)}$ & $\frac{0.4-5.7 / 2.2}{1.5(21)}$ & $\frac{0.5-9.1 / 2.9}{2(27)}$ \\
\hline $\mathrm{FeO}, \%$ & $\frac{0.04-0.43 / 0.14}{0.1(17)}$ & $\frac{0.09-0.39 / 0.21}{0.11(17)}$ & $\frac{0.01-0.38 / 0.13}{0.09(21)}$ & $\frac{0.06-0.4 / 0.15}{0.09(27)}$ \\
\hline $\mathrm{MnO}, \mathrm{ppm}$ & $\frac{1090-2000 / 1413}{287(17)}$ & $\frac{751-2700 / 1433}{540(17)}$ & $\frac{500-1600 / 915}{313(21)}$ & $\frac{\leq 50-960 / 557}{255(27)}$ \\
\hline $\mathrm{S}, \mathrm{ppm}$ & $\frac{430-1100 / 600}{213(9)}$ & $\frac{380-520 / 438}{54(6)}$ & $\frac{260-570 / 338}{94(9)}$ & $\frac{100-360 / 270}{60(13)}$ \\
\hline $\mathrm{P}_{2} \mathrm{O}_{5}, \mathrm{ppm}$ & $\frac{\leq 500-1040 / 483}{215(17)}$ & $\frac{\leq 500-1720 / 877}{389(17)}$ & $\frac{\leq 500-6800 / 1315}{1513(21)}$ & $\frac{\leq 500-4000 / 1480}{90(27)}$ \\
\hline $\mathrm{Na}_{2} \mathrm{O}, \mathrm{ppm}$ & $\frac{\leq 500-4500 / 1240}{1346(17)}$ & $\frac{\leq 500-2000 / 605}{605(17)}$ & $\frac{\leq 500-1700 / 399}{392(9)}$ & $\frac{\leq 500-2200 / 400}{434(27)}$ \\
\hline$d_{104}, \AA$ & $\frac{2.888-2.893 / 2.890}{0.001(22)}$ & $\frac{2.888-2.891 / 2.890}{0.0008(14)}$ & - & - \\
\hline $\begin{array}{l}\text { Calculated mol\% } \\
\mathrm{CaCO}_{3}\end{array}$ & $\frac{51.4-52.9 / 52}{0.33(22)}$ & $\frac{51.5-52.3 / 51.9}{0.25(14)}$ & - & - \\
\hline $\begin{array}{l}\text { Calculated mol\% } \\
\mathrm{FeCO}_{3}\end{array}$ & $\frac{0.065-0.69 / 0.24}{0.17(22)}$ & $\frac{0.18-0.63 / 0.37}{0.17(14)}$ & - & - \\
\hline
\end{tabular}

* Samples with calcite and gypsum cement are not included in the table. 


\section{RESULTS}

\section{Lithology}

Considering different rock classifications, the collected samples were subdivided into four lithological rock groups based on chemical parameters. To discriminate dolostone (limestone) from dolomitic marlstone (marlstone), the 25\% limit of IR content has been used for a long time in the Baltic States (Vingissaar et al. 1965). However, this limit is rarely used in the British and American literature (Nestor 1990; Miall 2000). Concerning our collection, the IR limits $<25 \%$ for dolostone and $25-50 \%$ for dolomitic marlstone are suitable for discriminating naturally different rock groups. The mixed carbonate-siliciclastic rock type was distinguished nearly 20 years ago (Mount 1985), and although some dissenting opinions exist, the classification range $50-70 \%$ IR is well-founded (Miall 2000; Selley 2000) and also applicable to our rock collection.

Taking into account nearly complete dolomitization of carbonate rocks in the six boreholes studied, we could discriminate four general rock groups using only one chemical parameter, IR. From 96 rock samples we got the following groups (Fig. 4, Table 1): (1) dolostone group including 23 samples; (2) dolomitic marlstones represented by 17 samples; (3) the group of mixed carbonate-siliciclastic rocks including 9 cement-rich siltstone samples, 8 cement-supported sandstone samples, 6 samples of dolomitic marlstone rich in detrital minerals, and 1 dolostone sample, the last one containing abundant detrital-rich interlayers; (4) siliciclastic rocks represented by 23 sandstone and 9 siltstone samples with grain-supported texture.

Dolostones are found mainly in the lower part of the Narva Stage. They may form up to $50 \%$ of the Vadja Formation and about 3-15\% of the Leivu Formation.

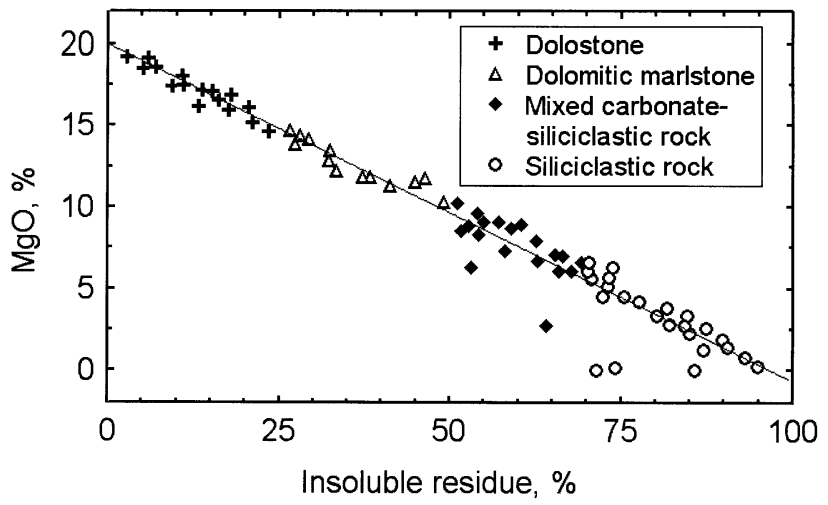

Fig. 4. Insoluble residue (IR) versus $\mathrm{MgO}$ content, measured by wet chemical analysis for carbonate rocks and by XRF analysis for siliciclastic rocks. In dolostones IR $<25 \%$, dolomitic marlstones $25<\mathrm{IR}<50 \%$, mixed carbonate-siliciclastic rocks $50<\mathrm{IR}<70 \%$, and siliciclastic rocks IR $>70 \%$. 
Dolostone layers occur also in the upper parts of the Pärnu and Rēzekne stages, and as thin interbeds in the Kernave Formation of the Narva Stage and in the Aruküla Formation. The studied dolostones are light grey and light brownishgrey. Dolostone layers are up to $3 \mathrm{~m}$ thick, alternating with dolomitic marlstone and claystone. Massive and medium- to thin-bedded dolostone is present, with beds being commonly about $1-10 \mathrm{~cm}$ thick. The bedding is horizontal, rarely inclined. The bedding surfaces may be even; often they are wavy and lenticular and covered by grey or brownish-grey clay films. Commonly microstructure is massive, in some cases laminated. The thickness of laminae is $0.2-1 \mathrm{~mm}$. Microlamination is wavy and lenticular (Fig. 5A). The matrix of dolostone is cloudy, predominantly aphanocrystalline $(<0.005 \mathrm{~mm})$ (Fig. 5A-D), rarely very finely crystalline $(0.005-0.01 \mathrm{~mm})$. The structure is often patchy, due to the variety of clay components and uneven pigmentation by iron minerals. The matrix contains
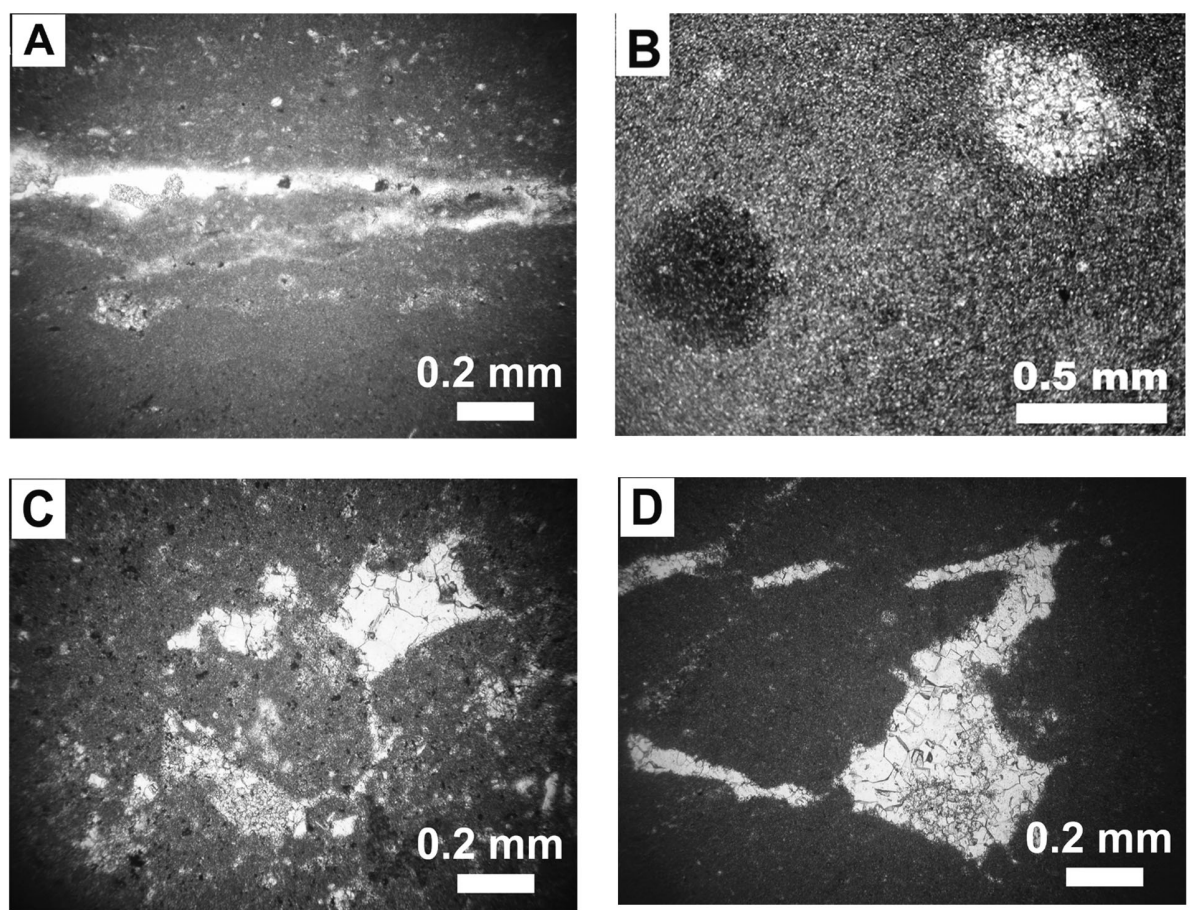

Fig. 5. Thin sections of dolostones in plane-polarized light. (A) Valga (10) borehole, $175.4 \mathrm{~m}$. Aphanocrystalline, cloudy, wavy laminated. Along bedding surface concentrations of detrital minerals and clear dolomite grains are seen. (B) Taagepera borehole, $180.6 \mathrm{~m}$. Very finely crystalline, cloudy, containing pockets filled with transparent authigenic fine-crystalline dolomite and goethite/ hematite pigmented patches. (C) Valga (10) borehole, $171.5 \mathrm{~m}$. Irregular and angular vugs filled with transparent medium-crystalline authigenic dolomite in the aphanocrystalline cloudy matrix. (D) Valga (10) borehole, $218.3 \mathrm{~m}$. Quadratic vugs and branching fractures in the cloudy aphanocrystalline matrix filled with transparent medium-crystalline authigenic dolomite. 
scattered crystals of pyrite and goethite/hematite (both $0.005-0.01 \mathrm{~mm}$ ), sometimes scattered finely crystalline transparent grains and rhombs of authigenic dolomite $(0.02-0.05 \mathrm{~mm})$. Rhombic grains are often zoned. Dolostone contains pockets or vugs $(0.1-0.8 \mathrm{~mm})$ and irregular, often intricately branching and wavy fractures filled with clear finely to medium-crystalline $(0.02-0.1 \mathrm{~mm})$, in rare cases coarsecrystalline (up to $0.3 \mathrm{~mm}$ ) dolomite. Vugs and filled fractures are scattered in the cloudy matrix (Fig. 5B-D). Their configuration may be rounded, irregular or angular-quadratic (Fig. 5C,D). Angular vugs are presumably formed according to dissolution of cubic minerals and following the filling of the caverns with authigenic dolomite. Abundant transparent fine-crystalline dolomite grains occur in the matrix surrounding such vugs (Fig. 5C). The vugs are frequently connected with dolomite-filled fractures (Fig. 5D). Sometimes partings of cloudy original dolostone or partly recrystallized matrix are preserved in the vugs, indicating inhibited recrystallization and replacements in cavities. Elongated vugs and filled fractures are often oriented along bedding planes, but irregular fractures of different directions are also observed (Fig. 5D). The width of the fractures varies from 0.01 to $0.15 \mathrm{~mm}$. Pores are often found in filled vugs and fractures. Sometimes fine-crystalline authigenic transparent and semitransparent dolomite occurs in interlayers containing subrounded pellets $(0.1-0.15 \mathrm{~mm})$ of cloudy dolostone.

Insoluble residue $(2.7-23.5 \%)$ is mainly represented by muddy partings $(<0.01 \mathrm{~mm})$ consisting mostly of illite with considerable amounts of chlorite. In some cases mixed-layer montmorillonite-chlorite, illite-smectite, illite-chlorite, and illite-montmorillonite occur. Detrital partings $(>0.01 \mathrm{~mm})$ make commonly $0.3-5 \%$ of IR, in rare cases up to $30 \%$. Grains $0.01-0.063 \mathrm{~mm}$ in size are clearly dominating. In very rare cases some sand grains are found. Detrital minerals are often concentrated along bedding surfaces, together with frequent finely crystalline authigenic dolomite grains (Fig. 5A). Also part of the detrital grains is scattered in the matrix. Quartz usually dominates among detrital minerals, accounting for about $50-80 \%$. The content of feldspars (mainly orthoclase) is about $15-30 \%$. Mica minerals are very variable in content, prevailing only in rare cases.

Dolomitic marlstone is abundant in the Narva Stage, dominating in the Leivu Formation. The content of dolomitic marlstone in the Leivu Formation is commonly $80-90 \%$, and about $40-70 \%$ in the Vadja Formation. In the Kernave Formation it is found in different proportions, forming only $10-15 \%$ of the sequence in the central part of Estonia (Tartu (453) and Valga (10) drill cores), but 30-60\% of the sequence in the other regions. Dolomitic marlstone occurs as interbeds in the Viljandi Member of the Aruküla Stage and is abundant in the upper part of the Rēzekne Stage in eastern Estonia, where the Rēzekne Stage is represented by the Mehikoorma Formation (Värska (6) and Võru cores).

Dolomitic marlstones are mainly grey, often with violet or greenish shade in the Rēzekne Stage and the Vadja and Leivu formations. Mottled reddish-browngreenish-grey varieties prevail in the upper part of the Leivu Formation, in the Kernave Formation, and in the Viljandi Beds. The thickness of dolomitic marlstone beds varies from 0.1 to $1 \mathrm{~m}$, sometimes up to $10 \mathrm{~m}$. Dolomitic marlstone alternates 
with claystone and dolostone in the Rēzekne Stage, Vadja and Leivu formations, and with clay- and siltstone beds in the Kernave Formation and Viljandi Beds. The structure of marlstone beds is commonly massive, often patchy. The matrix is indistinctly-unevenly pigmented with goethite/hematite (Fig. 6A,B). The patchy distribution of pockets rich in clastic material is observed in the Kernave and Leivu formations. Microlamination occurs more frequently in the upper part of the Leivu Formation and in the Kernave Formation, and is mainly lenticular-wavy. A specific variety, $0.2-10 \mathrm{~m}$ thick breccia-like dolomitic marlstone is common in the basal part of the Vadja Formation. In dolomitic marl unsorted clasts of dolostone, dolomitic marl, in rare cases also silt- and sandstone are embedded (Kleesment \& Mark-Kurik 1997). The content of subrounded clasts with a diameter of $0.5-3 \mathrm{~cm}$, rarely up to $6 \mathrm{~cm}$, varies from 10 to $80 \%$. The breccia layer is wavy, microlaminated (Fig. 6C), containing authigenic gypsum in southeastern Estonia. Sometimes interlayers of authigenic gypsum up to $10 \mathrm{~cm}$ thick occur in this level (Fig. 6D). Among the studied drill cores the breccia layer is well represented in the Tartu (453) core (thickness $6.4 \mathrm{~m}$ ), but was not determined in the Taagepera core.
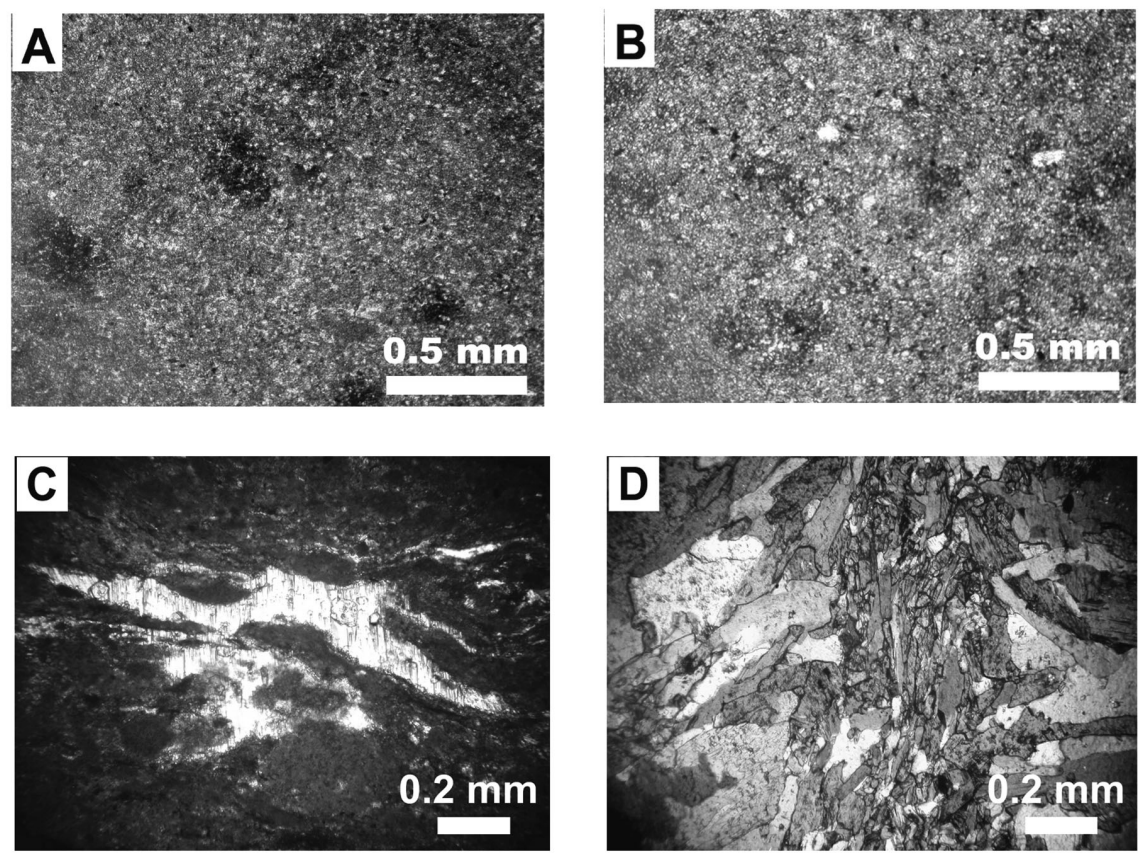

Fig. 6. Thin sections of dolomitic marlstones in plane-polarized light. (A) Valga (10) borehole, $224.3 \mathrm{~m}$. Very finely crystalline, cloudy, patchy pigmented with goethite/hematite. (B) Värska (6) borehole, $256.0 \mathrm{~m}$. Finely crystalline, authigenic medium-crystalline dolomite, patchy pigmented with goethite/hematite in the cloudy matrix. (C) Värska (2) borehole, $252.0 \mathrm{~m}$. Wavy authigenic gypsum laminae in a breccia layer. (D) Värska (2) borehole, $247.5 \mathrm{~m}$. Laminae of authigenic gypsum in the lower part of the Vadja Formation. 
Dolomitic marlstone is very fine- to fine-crystalline $(0.005-0.01 \mathrm{~mm})$, cloudy or semitransparent (Fig. 6A). Finely and variously crystalline varieties are also found (Fig. 6B). Sometimes clear medium-crystalline rhombs of authigenic dolomite are scattered in the matrix. In rare cases the rock is penetrated by fractures which may be filled with medium-crystalline authigenic dolomite. Insoluble residue $(25-50 \%)$ is mainly represented by muddy particles $(<0.01 \mathrm{~mm})$. The muddy fraction is characterized by a high content of illite (60-80\%) accompanied by chlorite. Sometimes admixture of mixed-layer chlorite-montmorillonite is recorded (up to $20 \%$ ). The content of detrital particles $(>0.01 \mathrm{~mm}$ ) is $5-20 \%$, with silty ones $(0.01-0.063 \mathrm{~mm})$ clearly dominating. The proportion of sand fraction is commonly $0.1-3 \%$. Detrital particles with a size of $0.01-0.05 \mathrm{~mm}$, forming $2-5 \%$ of the rock, are sporadically scattered in the matrix, however, enrichment by detrital material is observed in thin interlayers $(0.2-0.4 \mathrm{~mm})$. Patchy enrichment by detrital partings occurs in the upper part of the Kernave Formation and in the Aruküla Stage. Micas are usually dominating among detrital minerals, accounting for $40-65 \%$. The content of quartz is mainly $30-50 \%$ and of feldspars $10-20 \%$. Quartz grains are subangular and often corroded.

Siliciclastic rocks are represented by sand- and siltstones in the studied sequence. The prevailing sandstone complexes are usually up to $10-20 \mathrm{~m}$ thick, while siltstones occur as $10-50 \mathrm{~cm}$ thick interbeds. Loose varieties clearly dominate among sandstones where clay cement forms $5-10 \%$ of the rock. The cement content of siltstones is commonly $10-30 \%$. Cement is mainly represented by illite accompanied by chlorite. The admixture of kaolinite and a mixed illitemontmorillonite layer occur in the siliciclastic rocks of the Pärnu and Rēzekne stages; kaolinite admixture is observed also in the siliciclastic rocks of the Burtnieki Stage.

Carbonate-cemented siliciclastic rocks form $4-6 \%$ of the sequence of the Rēzekne and Pärnu stages containing carbonate interbeds. The content of cemented siliciclastic rocks reaches $20 \%$ in the Rēzekne Stage in the Värska (6) core where the upper part of this unit is composed of dolomitic rocks (Fig. 2). Frequent intercalation of siliciclastic and dolomitic rocks occurs in the Leivu and Kernave formations where $20-60 \%$ of siliciclastic rocks are dolomite-cemented. Dolomitecemented siliciclastic rocks account for $5-10 \%$ in the Aruküla Stage, while in the sequence of the Burtnieki Stage dolomite-cemented interlayers are extremely rare, lying as thin beds $(5-20 \mathrm{~cm})$ in clay interbeds and having often globular structure. Such a structure has also been observed in the sequences of the Aruküla Stage, in some cases also in the Kernavè Formation and Pärnu and Rēzekne stages. Carbonate-cemented siliciclastic rocks occur mostly as $5-20 \mathrm{~cm}$ interbeds, intercalating with claystone, dolomitic marl, and/or poorly cemented siliciclastic rocks or containing clay-coated surfaces. Sometimes the Leivu and Kernave formations include dolomite-cemented layers up to $1 \mathrm{~m}$ thick, which, as a rule, contain poorly cemented interlayers. Lens-shaped dolomite-cemented layers lie on the claystone beds in the upper part of the Aruküla Stage and in the Burtnieki Stage. Often conglomeratic beds are cemented and contain remains of fishes and brachiopods throughout the section. 
The general mineralogical composition of loosely and carbonate cemented siliciclastic rocks is similar. Quartz dominates, being accompanied by K-feldspars and mica minerals (Kleesment \& Mark-Kurik 1997). Greater differences are observed in the content of accessory minerals. During diagenesis of loosely cemented siliciclastic rocks magnetite was replaced by goethite. Garnet, titanite, amphiboles, pyroxenes, and possibly also corundum have partially dissolved in poorly cemented sand- and siltstones, which alternate with layers of carbonate and argillaceous rocks. Authigenic apatite and overgrowths of detrital feldspars were also formed in such siliciclastic layers (Kleesment \& Paap 1978; Kleesment 1984, 1998).

Cemented siliciclastic rocks contain mostly dolomite cement in the studied sequence. Only in few cases calcite cement was found in the lower part of the sequence in East Estonia (Võru core). Additionally, some interbeds of gypsum cement occur in the Vadja Formation in the Värska (6) core. Calcite- and gypsumcemented samples deviate clearly from general regularities and fall below the correlation line (Fig. 4). Dolomite-cemented layers are usually only 5-10 cm thick. However, often cemented beds are 1-2 m thick, but they have a thin-bedded structure, intercalating with thin clay- or marlstone interbeds or clay surfaces. Commonly cement forms 30-40\% (Fig. 7A), more rarely 10-30\% (Fig. 7B,C) of the rock. Cement is unevenly distributed, whereas grain-supported and cementsupported partings alternate (Fig. 7A). The matrix is also patchy pigmented by goethite/hematite. Rare pyrite-cemented patches are present. Cement is represented by transparent or slightly cloudy finely to medium-crystalline $(0.03-0.25 \mathrm{~mm})$ dolomite rhombs, sometimes having zonal structure (Fig. 7A). As a rule, in grainsupported partings the cement grains are coarser (Fig. 7A). In siltstones cement is finer than in sandstones. Dolomite rhombs are sometimes surrounded by tiny ferrian coatings. Tiny pyrite crystals may be scattered in the matrix. Calcite cement is medium- to coarse-crystalline and extremely clear (Fig. 7D). Detrital grains are often surrounded by dolomite rims (Fig. 7B,C). Pyrite crystals have clear carbonate rims. Corrosion of detrital grains by cement is widespread (Fig. 7B,D), being relatively strong in the Rēzekne and Pärnu sequences.

Mixed carbonate-siliciclastic rocks consist of three main components: siliciclastic, muddy, and carbonate or some other chemical sediment (gypsum, etc.). The carbonate part of these rocks may occur as matrix containing thin interlayers rich in clastic partings, include scattered detrital grains and serve as cement in the clastic sediment. In the last case these rocks are actually cement-supported sandstones or coarse-grained siltstones in which carbonate content is up to $50 \%$. Carbonate cement is represented mainly by slightly cloudy fine-crystalline (Fig. 8A) or medium- to coarse-crystalline clear (Fig. 8B) dolomite. Rare fine interlayers with calcite cement are present (Fig. 8C). Similar to siliciclastic rocks, those samples fall below the correlation line (Fig. 4). Cement distribution is commonly patchy, with spots of pyrite cement. Detrital grains and pyrite crystals are often coated with carbonate rims (Fig. 8B), indicating that pyrite has formed earlier than carbonate. In rare cases calcite is represented by clear medium- to coarsecrystalline varieties. The conditions and mechanism of mixed carbonate-sandstone formation are similar to those of cemented siliciclastic rocks described 

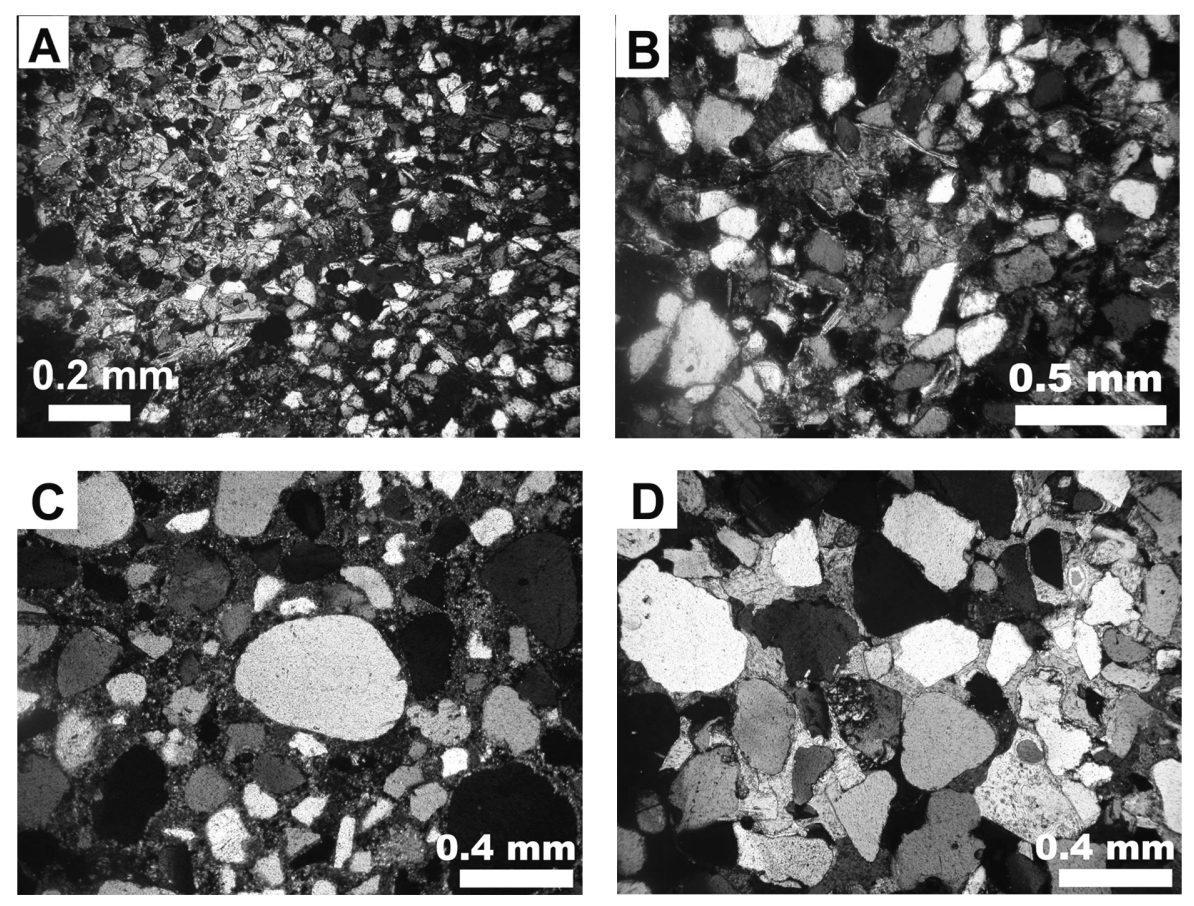

Fig. 7. Thin sections of siliciclastic rocks with crossed polars. (A) Ruhnu (500) borehole, $10 \mathrm{~m}$. Very fine-grained sandstone. Patchy grain-supported and cement-supported partings alternate. Cement is finer-crystalline in grain-supported areas than in matrix-supported ones. (B) Vorru borehole, $308.0 \mathrm{~m}$. Fine-grained sandstone. Cement (15-20\%) is represented by fine- to medium-crystalline clear dolomite. Corroded quartz grains, rimmed by dolomite are present. (C) Värska (6) borehole, $267.5 \mathrm{~m}$. Poorly sorted, medium- to coarse-grained sandstone cemented by very fine-crystalline dolomite forming $20-25 \%$ of the rock. (D) Võru borehole, $340.5 \mathrm{~m}$. Medium- to coarse-grained sandstone cemented by clear medium-crystalline calcite forming about $20 \%$ of the rock. Quartz grains are often corroded.

above. The latter also intercalated with loosely cemented sandstones containing interbeds of claystone or dolomitic rocks.

According to the composition depending on depositional conditions, nine dolomitic siltstones, six siliciclastic dolomitic marlstone, and one dolostone belong to mixed rocks. Transitional varieties of fine-grained siliciclastic and carbonate rocks are more frequent in the upper units, in the lower part of the Aruküla Stage and in the Kernave Formation. Here thin-bedded structure of rocks is common, showing intercalation of sand-, silt-, and claystones with interbeds of dolomitic marl. As seen in thin sections, these rocks have small-scale sedimentary structures, the laminae containing different amounts of matrix and cement (Fig. 8D). As a rule, the dolomite is very fine- to fine-crystalline in matrix-rich interbeds and fine- to medium-crystalline in detritus-rich interbeds. Indistinctly wavy-bedded structures are common (Fig. 8D). The thickness of the laminae is $0.2-2 \mathrm{~mm}$. Mica flakes are oriented sub-parallel to bedding and rock often contains dolomitic 

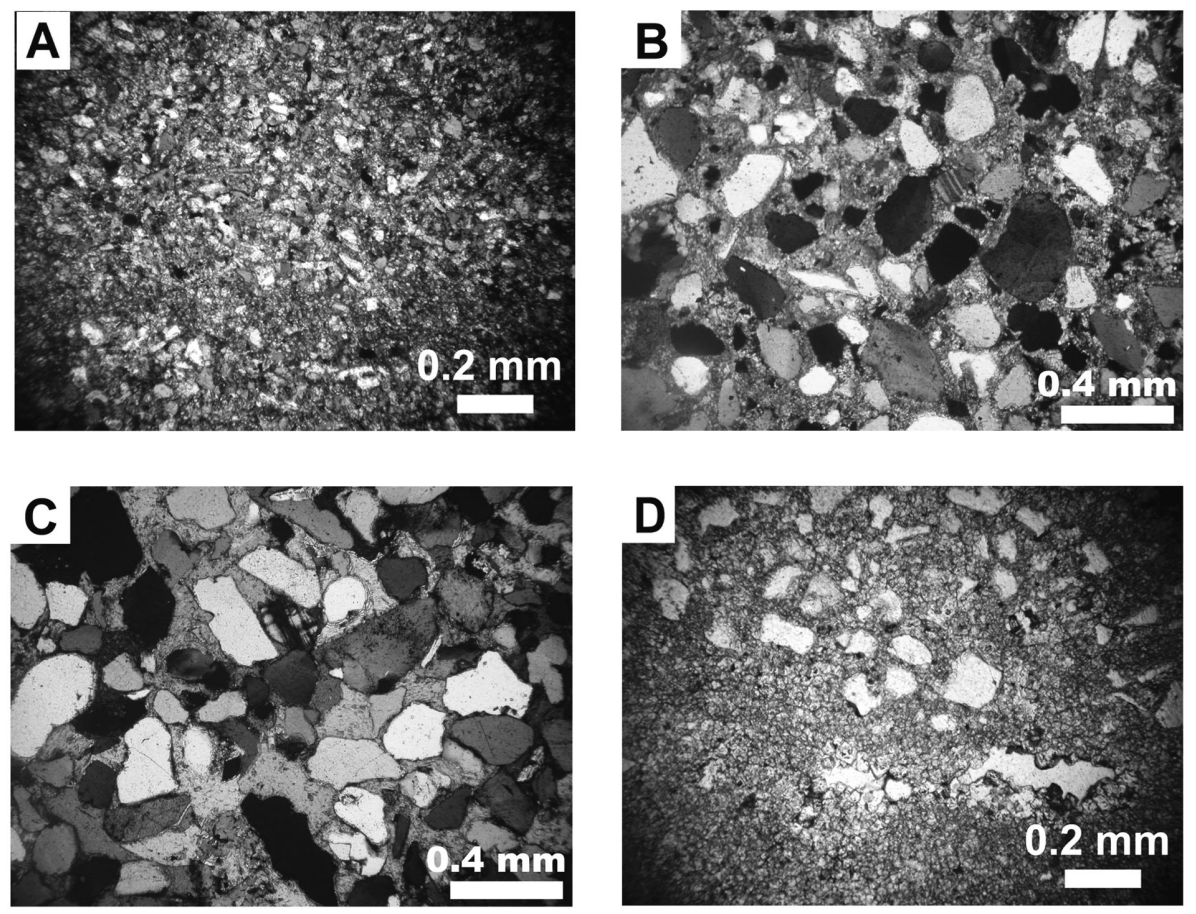

Fig. 8. Thin section of mixed rocks with crossed polars. (A) Valga (10) borehole, $128.0 \mathrm{~m}$. Cementsupported siltstone. Cement is represented by fine-crystalline cloudy dolomite. (B) Taagepera borehole, $230.0 \mathrm{~m}$. Cement-supported, poorly sorted sandstone cemented with fine- to medium-crystalline dolomite. (C) Värska (6) borehole, $293.0 \mathrm{~m}$. Cement-supported fine- to medium-grained sandstone. Patchy alternation of medium-crystalline clear dolomite and calcite cement. (D) Värska (2) borehole, $191.0 \mathrm{~m}$. Fine-crystalline dolomitic marl, enriched by detrital material. Often corroded detrital material is concentrated in laminae.

pellets in transitional to matrix-supported siliciclastic rocks. Being enriched in clastic component, these rocks are transitional to dolomitic marlstone. However, in most cases, mixed siliciclastic-carbonate rocks (transitional to dolomitic marl or dolostone) show clear small-scale lamination: alternation of aphanocrystalline dolostone or very fine-crystalline dolomitic marl with thin sandy or silty laminae where matrix is fine- to medium-crystalline. Some quartz grains are corroded (Fig. 8D).

\section{Correlation of gamma-ray logs}

A natural GR log reflects mainly the clay content of all the rocks and the $\mathrm{K}$-feldspar content of the siliciclastic-bearing rocks in the Devonian sedimentary sequence. Anomalous accumulation of radioactive isotopes $\left(\mathrm{U}, \mathrm{Th}\right.$, and $\left.\mathrm{K}^{40}\right)$ is usually registered in highly argillaceous carbonate and siliciclastic rocks owing to their high potassium content. Increase in iron minerals, which generally correlates 
with the clay content of the studied rocks, may increase GR readings because iron minerals and organic matter can sorb radioactive elements. The studied rocks are known to be relatively poor in organics.

The lowest GR readings were registered against quartz sandstones, which are poorest in clay admixture. Gamma-ray values increase in siltstones and are the highest in claystones. Gamma-ray readings against dolostones are usually higher than in sandstones, but may be the same as for dolomitized sandstones. Dolomitic marlstones are characterized by higher readings, similar to those registered for siltstones and dolomitized siltstones. The highest GR values characterize argillaceous siltstones, silty claystones, and claystones.

The lowest GR reading was registered against the Burtnieki and Pärnu stages composed predominantly of siliciclastic rocks. The Narva Stage, represented mainly by carbonate rocks, was reflected by higher GR readings with relatively stable amplitude. The overlying Aruküla Stage is characterized by a lower average amplitude which varies in a wide range and depends on the clay content of siliciclastic rocks and on carbonate cementation (Figs. 2, 3).

\section{Mineralogical parameters}

According to XRD analyses, made by D. Gurfel in the laboratory of the IG TUT in the 1970s, Devonian dolostones contain besides dominating dolomite, admixture of siderite, rarely of ankerite. Using the $\mathrm{FeO}$ content of dolostone measured by wet chemical analysis, we calculated the $\mathrm{mol} \% \mathrm{FeCO}_{3}$ content (Table 1), which was lower than 1. It means that the studied dolostones and dolomitic marlstones did not include ankerite (Goldsmith \& Graf 1958; Reeder \& Sheppard 1984; Tucker \& Wright 1994) and we could use measurements of $d_{104}$ for calculating the $\mathrm{CaCO}_{3}$ content of mineral dolomite. The lattice parameter $d_{104}$ was measured in 22 dolostone and 14 dolomitic marlstone samples. The $d_{104}$ value obtained for dolostone was $2.888-2.893 \AA$, mostly $2.890 \AA$ (Fig. 9). The mol\%

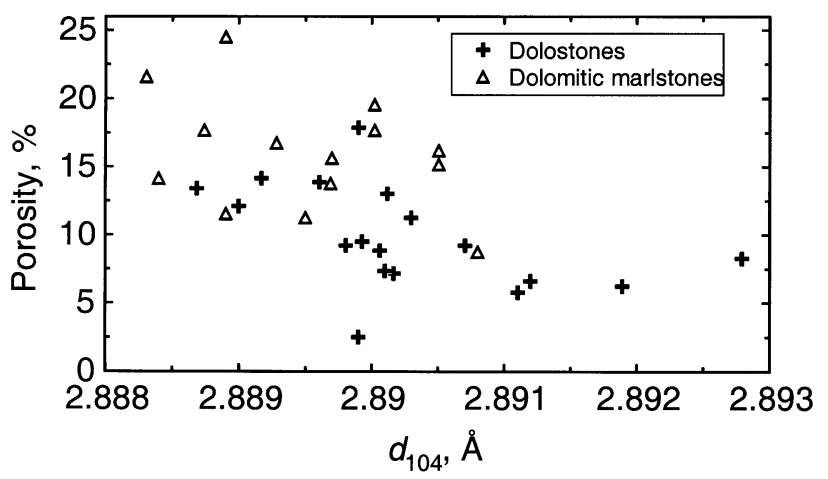

Fig. 9. The $d_{104}$ value in dolomite and dolomitic marlstones versus porosity measured by wet chemical analysis. The range of $d_{104}$ is $2.8883-2.8912 \AA$ for both dolostone and dolomitic marlstone. Samples with higher $d_{104}(2.892-2.893 \AA)$ are from the Tartu (453) borehole. 
$\mathrm{CaCO}_{3}$ content of dolomite was 51.4-52.9, with the mean value of 52. For dolomitic marl the measured $d_{104}$ value was $2.888-2.890 \AA$, and the $\mathrm{mol} \% \mathrm{CaCO}_{3}$ content of dolomite was 51.5-52.3, on average 51.9 (Table 1).

\section{Geochemical parameters}

The $\mathrm{MgO}$ content of dolostones measured by X-ray fluorescence was $15.2-$ $19.7 \%$ and the $\mathrm{MgO} / \mathrm{CaO}$ ratio was $0.62-0.75$. The ratio was the highest for the given IR among all known dolostones of different genesis in the Estonian bedrock sequence (Šogenova et al. 2003). The $\mathrm{MgO}$ content of dolomitic marlstones was $10.3-15.6 \%$ and $\mathrm{MgO} / \mathrm{CaO}$ ratio $0.6-0.87$. Clear negative correlation of $\mathrm{MgO}$ with IR was recorded for all studied Devonian rocks. Only siliciclastic and mixed samples with calcitic and gypsum cement mainly from the Värska (6) borehole (and one sample from both the Võru and Ruhnu (500) drill cores) deviate from the general trend, occurring below the correlation line (Fig. 4).

The measured $\mathrm{FeO}$ content and calculated $\mathrm{mol} \% \mathrm{FeCO}_{3}$ were relatively low in dolostones and dolomitic marlstones, the mean values being, respectively, $0.14 \%$ and $0.24 \mathrm{~mol} \%$ in dolomites and $0.21 \%$ and $0.37 \mathrm{~mol} \%$ in dolomitic marlstones. Total iron content had high positive correlation (0.86) with $\mathrm{Al}_{2} \mathrm{O}_{3}$ as an indicator of clay in all studied rocks (Fig. 10). Total iron had positive correlation with IR $(R=0.63)$ and negative correlation with $\mathrm{MgO}(-0.55)$ in dolostones.

$\mathrm{MnO}$ concentration was higher in Devonian dolostones (1100-2000 ppm) and dolomitic marlstones (800-2700 ppm) than in underlying Silurian dolostones (200-1500 ppm) (Šogenova et al. 2003). It was also higher in carbonate rocks than in mixed (500-1600 ppm) and siliciclastic (<960 ppm) rocks. MnO content correlated with total iron $(R=0.51)$ only in dolostones (Fig. 11A), but it correlated with $\mathrm{MgO}$ in all other rocks (Fig. 11B). MnO showed positive correlation with $\mathrm{MgO}(R=0.72)($ Fig. 11B), negative correlation with IR $(R=-0.74)$, and no

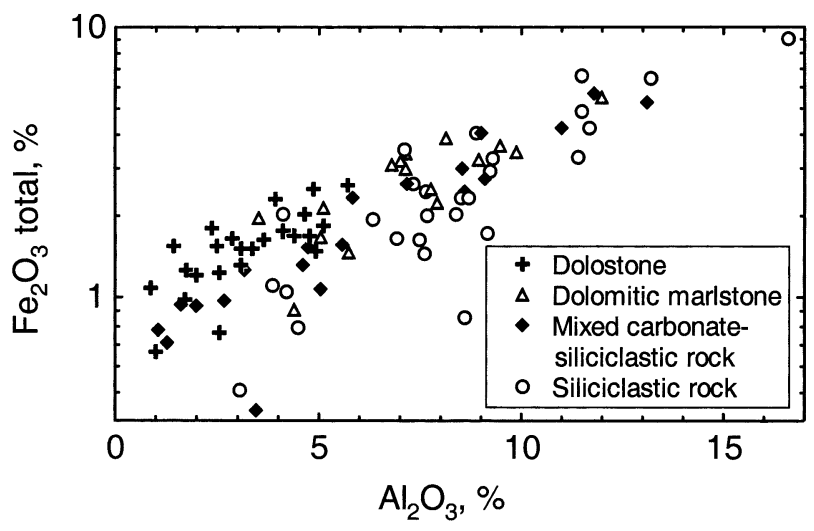

Fig. 10. $\mathrm{Al}_{2} \mathrm{O}_{3}$ versus $\mathrm{Fe}_{2} \mathrm{O}_{3}$ total in all examined rocks. 

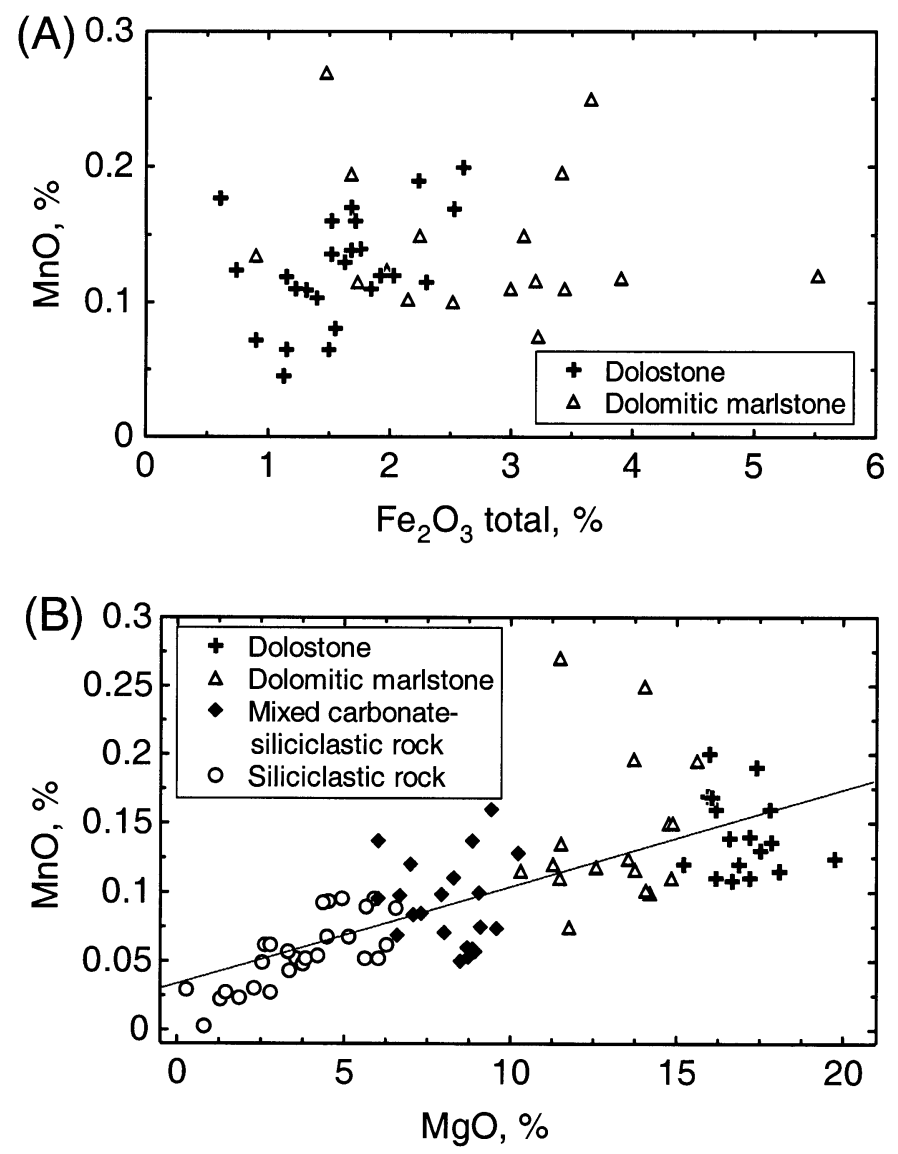

Fig. 11. (A) $\mathrm{MnO}$ content versus total iron content in dolostone and dolomitic marl. (B) $\mathrm{MnO}$ content versus $\mathrm{MgO}$ content in all examined rocks.

correlation with total iron and clay in all studied Devonian rocks taken together. $\mathrm{MnO}$ content did not correlate with iron or clay contents in the rocks with IR $>25 \%$. In all dolostones $\mathrm{MnO}$ had negative correlation with depth in samples taken from separate boreholes, while $\mathrm{MgO}$ had positive correlation with depth (0.61). In dolomitic marlstones $\mathrm{MnO}$ content had significant negative correlation $(-0.55)$ with $\mathrm{CaCO}_{3}$ entering dolomite and with depth $(-0.42)$.

\section{Porosity}

Dolostones had the lowest porosity among the studied rocks, which varied in the range $2.5-21.7 \%$ (Table 1, Fig. 12) and, except for one sample, was lower than $17.9 \%$. However, their porosities for the given IR may differ by more than $10 \%$. The porosity of mixed carbonate-cemented rocks was close to that of dolostones except 

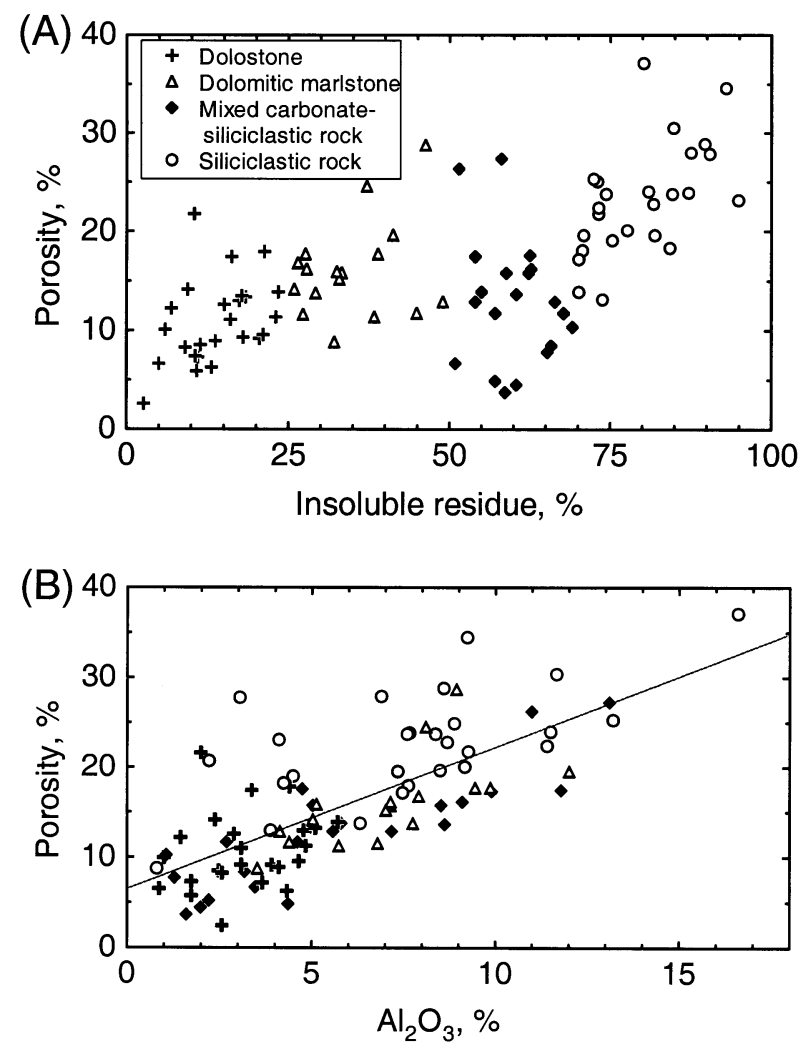

Fig. 12. (A) Porosity versus insoluble residue content. (B) Porosity versus $\mathrm{Al}_{2} \mathrm{O}_{3}$ content in all rocks.

for two samples, ranging from 3.6 to $17.5 \%$. (Fig. 12A). Marlstones had higher porosity in the range $8.7-28.8 \%$. The porosity of siliciclastic rocks was the highest (13-37.1\%); only one sandstone with calcite cement had lower porosity $(8.7 \%)$.

For all Devonian rocks we could observe general positive correlation of porosity with IR (Fig. 12A) and $\mathrm{Al}_{2} \mathrm{O}_{3}$ as an indicator of clay content (Fig. 12B). The correlation coefficient between porosity and $\mathrm{Al}_{2} \mathrm{O}_{3}$ content for all studied rocks taken together was 0.73 . The coefficient was 0.71 for dolostones and dolomitic marlstones, 0.85 for mixed rocks, and 0.58 for siliciclastic rocks. The coefficient showing negative correlation between porosity and depth for siliciclastic and mixed rocks was not high but significant $(R=-0.37)$.

\section{DISCUSSION}

The lattice parameter $d_{104}$ determines the $\mathrm{mol} \% \mathrm{CaCO}_{3}$ content of dolomite, allowing discrimination of mineral dolomite with low $\mathrm{Fe}$ and $\mathrm{Mn}$ contents. It can be used to distinguish dolostones of different genesis (Tucker \& Wright 1994). 
Earlier the parameter $d_{104}$ and mol\% $\mathrm{CaCO}_{3}$ were also used in investigations of dolomitization (Al-Hashimi \& Hemingway 1973), but now they have only secondrate importance in the reconstruction of dolomitization processes. Commonly the chemical composition, thin sections, stable carbon, oxygen and strontium isotopes, trace elements, and fluid inclusions are studied to describe the rate and character of the dolomitization process (Bathurst 1975; Burns \& Baker 1987; Il Lee \& Friedman 1987; Moore 1989; Whittaker \& Mountjou 1996), however, in some cases lattice parameter values are also significant (Macqueen et al. 1974). Today the $d_{104}$ value is mainly used to calculate the $\mathrm{Mg} / \mathrm{Ca}$ ratio in mineral dolomite, which besides the other indicators mentioned above is a significant parameter for dolomite identification (Warthmann et al. 2000).

In comparison with ideal dolomite $\left(d_{104}\right.$ equalling $2.886 \AA$ after Goldsmith \& Graf 1958 and $2.884 \AA$ according to Teedumäe et al. 1999), Devonian dolomites had a higher $d_{104}$ value (Fig. 9). This shows that Devonian dolomites are not fully stoichiometric as most of the natural dolomites, but close to stoichiometric. Taking into account that the error in $\mathrm{CaCO}_{3}$ calculation may be about $1 \mathrm{~mol} \%$ in the highCa region and $2.5 \mathrm{~mol} \%$ in the low-Ca region (Reeder \& Sheppard 1984), the real average value for our samples may be lower than calculated $\mathrm{mol} \% \mathrm{CaCO}_{3}$ of the studied rocks $(51.4-52.9$, on average $52 \mathrm{~mol} \%)$. Such data $\left(51-52 \% \mathrm{CaCO}_{3}\right)$ are characteristic of shallow marine (near-surface) dolostone of early diagenetic origin associated with evaporites, indicating arid climate (Tucker \& Wright 1994).

$\mathrm{Mn}$ and Fe are very sensitive and most useful indicators of redox and source potential of the ambient waters from depositional through the diagenetic processes (Brand 1994). Trace elements in dolomitized rocks can provide information on the nature of dolomitization fluids. Early near-surface dolomites tend to have low $\mathrm{Fe}$ and $\mathrm{Mn}$ contents, since most near-surface fluids are oxidizing, contrasting with later, burial dolomites which may have high $\mathrm{Fe}^{2+}$ and $\mathrm{Mn}^{2+}$ precipitated from negative Eh pore fluids (Tucker \& Wright 1994). The low $\mathrm{Fe}^{2+}$ content of the studied dolostones supports their early near-surface genesis. Correlation of $\mathrm{MnO}$ with total iron content in dolostones and with $\mathrm{MgO}$ content in all other rocks may be an evidence of precipitation of Mn before early diagenetic dolomitization and its association with iron minerals in dolostones. This process may be typical of carbonate rocks from South Estonia. The MnO content of Estonian carbonate rocks has facies control and is higher in South Estonian drill cores than in North Estonia (Šogenova et al. 2003). Usually $\mathrm{MnO}$ has high correlation with total iron content in Estonian carbonate rocks (Shogenova et al. 2003).

Positive correlation of $\mathrm{MnO}$ content with $\mathrm{MgO}$, its negative correlation with IR, and no correlation with total iron and clay contents for all studied Devonian rocks taken together may be an evidence of Mn precipitation in siliciclastic and mixed rocks during later stages of dolomitization associated with burial.

According to the parameters described above, the studied dolostones belong presumably to early diagenetic type (Wolf \& Chilingarian 1994; McLane 1995) and have accumulated in tidal-flat environment poor in organic matter, under semiarid climate conditions (Shinn 1991). This supposition is supported also by 
the occurrence of desiccation cracks and chalcedony. Presumably dolomite does not precipitate directly from sea water. First calcium-carbonate sediments precipitated from magnesium-rich sea water and then, during the dissolution-precipitation reaction, part of Ca was replaced by $\mathrm{Mg}$, forming dolostone (McLane 1995). The formation of the patchy structure and the porphyrotopic texture are connected in the following compaction process (Figs. 5B; 6A,B). Characteristic crooked microfracturing of rocks was formed during their compaction (Fig. 5A,C,D). The occurrence of cracks and the thin-bedded structure of the sequence provided pathways for active fluid migration. Selective dissolution took place. The more soluble components, first of all limestone clasts, gypsum, and halite crystals, were dissolved and vugs were formed in the rocks (Fig. 5C,D). After that coarser dolomite crystals (up to $2-3 \mathrm{~mm}$ ) grew, filling the pore spaces partially or completely. In the late diagenetic processes circulating pore fluids influenced the rock. Fractures, bedding surfaces, and levels rich in detrital material provided pathways for the migration of fluids and, therefore, during diagenesis recrystallization took place especially in these levels. The filling of fractures and vugs with transparent medium- and coarse-crystalline dolomite is connected with late diagenesis (Zenger 1983; McLane 1995). The composition and structure of dolomitic marlstones indicate their accumulation in the same conditions as dolostone. Owing to the higher content of the muddy component, the processes of recrystallization in the early stage of diagenesis and, especially the following formation of patchy structures, proceeded more intensively.

Carbonate and clastic sediments commonly accumulated simultaneously in different parts of the same basin or in the same location at different times. Carbonate and clastic sedimentation may alternate on a continental margin as a result of sea-level change and tectonics. Epicontinental shallow sea sediments that accumulated in the studied area have a very complex cyclic structure indicating pulsatory nature of the sedimentation process. The accumulation of siliciclastic and carbonate sediments alternated recurrently. Mixed carbonate-siliciclastic rocks often deposited in transitional conditions. Traditionally, sedimentary petrology is divided into two separate fields of study: siliciclastic versus carbonate petrology. The results of several recent studies have demonstrated that, although the mixed sediments are not abundant, their investigation may give us information about the depositional history, dynamics, and interactions of facies. The complicated sequence in which siliciclastic, carbonate, and muddy rocks alternate, represented here, is a good basis for examining sediment accumulation and diagenetic cementation processes. Usually mixed carbonate-siliciclastic rocks are determined and classified considering only their sedimentation history (Doyle \& Roberts 1983, 1988; Miall 2000; Selley 2000), however, also diagenetic history makes its correctives (Mount 1985). Classification of these rocks is extremely complicated owing to their polygenetic nature.

Mixed rocks may have accumulated in different conditions. The sandy material embedded in dolomitic rocks was strongly altered by compaction. Post-sedimentary alteration processes were the most intensive in siliciclastic layers directly above 
and under carbonate complexes. Quartz, garnet, and other detrital minerals were subjected to corrosion and even dissolution (Kleesment \& Paap 1978; Kleesment 1984).

The dolomite cement in the sandstones of the Burtnieki and Aruküla stages has presumably developed from spots connected with fossil fragments, pyrite crystals or other centres, around which the first concretional lumps were formed. Cementation developed further and lumps joined with each other. In addition to earlier clay cement, dolomitic cement filled the pores. The process was usually accompanied by the shifting of grains. The clay matrix forms about $5-10 \%$ of claycemented sandstones, while the carbonate matrix takes considerably more space $(20-50 \%)$ in carbonate-cemented rocks (Figs. 7B-D; 8B,C). Presumably cement was formed in the same way in the other siliciclastic rocks. It is clear that the formation of dolomite cement proceeded after pyrite formation, in the middle phases of diagenesis. Diagenetic intrastratal fluids circulating in the terrigenous complexes have been enriched with dolomitic material. Interlayers of carbonate rocks in the Devonian sequence may be considered as a source of the dolomitic component. Dolomitization fluids were generated through the compaction of clay and dolomitic layers. In addition to cementation, the intrastratal fluids circulating in siliciclastic complexes affect more permeable, uncemented layers, causing etching of detrital grains, also mineral transformations, regeneration, and dissolution. Different kinds of mineral alterations taking place in the Devonian sequence during post-sedimentary processes have been studied: formation of authigenic leucoxene, anatase, apatite, pyrite, and goethite, dissolution of garnet, staurolite and kyanite, replacement of magnetite, amphiboles, titanium-bearing minerals and feldspar, formation of authigenic overgrowths of detrital feldspar grains (Kleesment \& Paap 1978; Kleesment 1984, 1998). In many cases cementation has strongly influenced physical properties of the rock, first of all porosity. In porosity value cement-supported sandstones are close to dolostones (Fig. 12A). Nonpermeable layers of fine-grained dolomitic rocks and claystones were formed contemporaneously with compaction and the above-mentioned alterations occurred only in bedding-planes and pores. Gradual cementation of detrital rocks reduced the porosity and prevented the continuation of many of the diagenetic changes mentioned above. The most marked transformations proceeded in highly permeable loose sandstones and especially in the levels containing dolomitic and clayey interlayers where saturated solutions circulated.

The calcitic cement in the studied sequence is late diagenetic in character and was formed as a replacement of dolomite cement. This process was accompanied by recrystallization phenomena.

As is known, porosity is a result of various geological, physical, and chemical processes and is generated during the genesis of the rock as "primary porosity" (clastic sedimentation, organogenesis) and/or during the geological history of the rock as "secondary porosity" (tectonic processes, chemical processes, dissolution, etc.) (Schön 1996). The main types of primary porosity may be intergranular 
(interparticle) and intragranular (intraparticle porosity), the main secondary porosity types are intercrystalline, vugular, and fissure or fracture porosity (Schopper 1982).

The porosity of Estonian carbonate rocks (including Devonian rocks) has positive correlation with clay content. This porosity was interpreted as primary. Secondary porosity of carbonate rocks is associated with dolomitization and was revealed on porosity versus insoluble residue graphs (Fig. 12A; Shogenova \& Puura 1997, 1998; Lind \& Shogenova 1998; Shogenova 1998; Shogenova et al. 1998, 2003).

As is known, dolomitization can cause both decrease and increase in porosity (Moore 1989). In general, the porosity of the studied rocks decreases with an increase in dolomite content. Early diagenetic dolomitization of carbonate rocks caused a decrease in their porosity owing to a higher grain density of mineral dolomite, but further diagenetic alterations of rock caused an increase in porosity owing to fracturing and leaching of carbonate rocks. Further on these pores may be filled (Fig. 5C,D).

The porosity of siliciclastic and mixed rocks decreases with carbonate cementation during diagenesis. The early diagenetic clay cement influenced the porosity of these rocks in opposite direction. Less clear is the decrease in porosity due to mechanical compaction, associated with the depth of the rocks. Negative correlation coefficients of porosity with depth for siliciclastic and mixed rocks are not high but significant $(R=-0.37)$. The absolute value of correlation is relatively low owing to shallow depth of the Estonian sedimentary basin. Such a correlation should be stronger in the deeper central and southern parts of the Baltic sedimentary basin, as has been described for the Baltic Cambrian rocks (Shogenova et al. 2001, 2002).

\section{CONCLUSIONS}

1. Epicontinental shallow sea sediments that have accumulated in the studied area have a cyclic structure indicating a pulsatory nature of the sedimentation process. The accumulation of siliciclastic and carbonate sediments alternated recurrently.

2. Dolostones and dolomitic marlstones are early diagenetic and have been deposited in the shallow nearshore tidal flat conditions. The sea water was saturated with $\mathrm{Mg}$. These rocks have changed during the next stages of diagenesis.

3. Cementation of siliciclastic rocks by Mg- and Mn-enriched fluids took place during middle and late diagenesis.

4. Two groups of mixed carbonate-siliciclastic rocks were determined in the studied sequence. Dolomitic siltstones and marlstones were formed during the sedimentation process as carbonate siltstones and marlstones and were dolomitized during early diagenesis. Mixed dolomitic sandstones, and sometimes siltstones, were formed during middle and late diagenesis by carbonate cementation of siliciclastic rocks. 
5. The porosity of rocks depends on several factors: clay content, mechanical compaction, dolomitization, and cementation. The porosity of all studied rocks increases with increasing accumulation of clay mainly during sedimentation. The porosity of carbonate rocks decreased owing to early diagenetic dolomitization and increased during middle and late diagenetic fracturing. The fractures, vugs, and pores were partly filled with dolomite crystals, which resulted in the reduction of porosity. The porosity of siliciclastic and mixed rocks decreased due to burial, and middle and late diagenetic cementation.

6. Main Devonian stratigraphic units are distinguished on the basis of GR readings, which are the highest against carbonate-rich rocks of the Narva Stage and the lowest against sandstones predominating in the Pärnu Stage. The most argillaceous siliciclastic rocks that deposited during Aruküla time are reflected by the highest variation in the GR amplitude.

\section{ACKNOWLEDGEMENTS}

This research was funded by the governmental target funding project No. 03320888s02 from the Ministry of Science and Education of Estonia and by the Estonian Science Foundation (grant No. 5726). We are grateful to T. Linkova for wet chemical analysis, T. Kallaste for XRD analysis, A. Jõeleht and $\mathrm{V}$. Shogenov for porosity measurements, Ü. Kestlane for thin-section preparation, and G. Baranov for photos. We are also thankful to L. Ainsaar and G. Stinkulis for constructive reviews of the manuscript.

\section{REFERENCES}

Al-Hashimi, W. S. \& Hemingway, J. E. 1973. Recent dedolomitization and the origin of the rusty crusts of Northumberland. J. Sedim. Petrol., 43, 82-91.

Bathurst, R. G. C. 1975. Carbonate Sediments and Their Diagenesis. Elsevier, Amsterdam.

Brand, U. 1994. Morphochemical and replacement diagenesis of biogenic carbonates. In Diagenesis IV (Wolf, K. H. \& Chillingarian, G. V., eds.), pp. 217-282. Elsevier, Amsterdam.

Burns, S. J. \& Baker, P. A. 1987. A geochemical study of dolomite in the Monterey Formation, California. J. Sedim. Petrol., 57, 128-139.

Doyle, L. \& Roberts, H. H. (conveners). 1983. AAPG/SEMP carbonate to clastic facies change I. Bull. Amer. Ass. Petrol. Geol., 67.

Doyle, L. J. \& Roberts, H. H. (eds.). 1988. Carbonate-Clastic Transitions. Elsevier, Amsterdam.

Goldsmith, J. R. \& Graf, D. L. 1958. Relations between lattice constants and composition of the Ca-Mg carbonates. Amer. Miner., 43, 84-101.

Il Lee, Y. \& Friedman, G. M. 1987. Deep-burial dolomitization in the Ordovician Ellenburger Group carbonates, West Texas and Southeastern New Mexico. J. Sedim. Petrol., 57, 544-557.

Jõeleht, A. \& Kukkonen, I. T. 2002. Physical properties of Vendian to Devonian sedimentary rocks in Estonia. GFF, 124, 65-72. 
Kleesment, A. 1984. The effect of secondary processes in the ratios of allothigenic minerals. Proc. Acad. Sci. Estonian SSR, 33, 70-77 (in Russian).

Kleesment, A. 1997. Devonian sedimentation basin. In Geology and Mineral Resources of Estonia (Raukas, A. \& Teedumäe, A., eds.), pp. 205-208. Estonian Academy Publishers, Tallinn.

Keesment, A. 1998. Authigenic overgrowths of detrital feldspar grains in the Devonian sequence of the East Baltic. Proc. Estonian Acad. Sci. Geol., 47, 229-241.

Kleesment, A. 2001. Devonian. In Valga (10) Drill Core (Põldvere, A., ed.), Estonian Geol. Sections, $3,6-8$.

Kleesment, A. \& Mark-Kurik, E. 1997. Middle Devonian. In Geology and Mineral Resources of Estonia (Raukas, A. \& Teedumäe, A., eds.), pp. 112-121. Estonian Academy Publishers, Tallinn.

Kleesment, A. E. \& Paap, Ü. A. 1978. About post-sedimentary alternation of garnet grains. Litol. Polezn. Iskopaemye, 28, 135-143 (in Russian).

Kleesment, A. \& Valiukevičius, J. 1998. Devonian. In Tartu (453) Drill Core (Põldvere, A., ed.), Estonian Geol. Sections, 1, 17-18.

Lind, I. \& Shogenova, A. 1998. Interpretation of acoustic velocity data for clay bearing carbonate rocks from the Palaeozoic deposits of Estonia and the Cenozoic and Mesozoic deposits of the Caribbean Sea. In Nordic Petroleum Technology Series IV: Research in Petroleum Technology (Middleton, M., ed.), pp. 111-123. Nordisk Energi-Forskningsprogram Ås.

Lippmann, F. 1973. Sedimentary Carbonate Minerals. Springer-Verlag, Berlin.

Macqueen, R. W., Ghent, E. D. \& Davies, G. R. 1974. Magnesium distribution in living and fossil specimens of the echinoid Perunella lasueuri Agassiz, Shark bay, Western Australia. J. Sedim. Petrol., 44, 60-69.

McLane, M. 1995. Sedimentology. Oxford University Press.

Miall, A. D. 2000. Principles of Sedimentary Basin Analyses. Springer, Berlin.

Moore, C. H. 1989. Carbonate Diagenesis and Porosity. Elsevier Science Publishers B.V., Amsterdam.

Mount, J. 1985. Mixed siliciclastic and carbonate sediments: a proposed first-order textural and compositional classification. Sedimentology, 32, 435-442.

Nestor, H. 1990. Some aspects of lithology of the Ordovician and Silurian rocks. In Field Meeting Estonia 1990. An Excursion Guidebook (Kaljo, D. \& Nestor, H., eds.), pp. 27-32. Estonian Academy of Sciences, Tallinn.

Plink-Björklund, P. \& Björklund, L. 1999. Sedimentary response in the Baltic Devonian Basin to postcollisional events in the Scandinavian Caledonides. GFF, 121, 79-80.

Priyatkin, A. \& Polyakov, E. 1983. Petrofizicheskie metody issledovaniya gornykh porod. Leningradskij Universitet, Leningrad (in Russian).

Reeder, R. J. \& Sheppard, C. E. 1984. Variation of lattice parameters in some sedimentary dolomites. Amer. Miner., 69, 520-527.

Schön, J. H. 1996. Physical Properties of Rocks: Fundamentals and Principles of Petriphysics. Handbook of Geophysical Exploration. Seismic Exploration, Vol. 18. Pergamon Press.

Schopper, J. R. 1982. Porosity and permeability. In Landolt-Börnstein - Group V. Geophysics and Space Research, Vol. 1: Physical Properties of Rocks, Subvol. 1 (Angenheister, G., ed.), pp. 184-304. Springer-Verlag, Berlin.

Selley, R. C. 2000. Applied Sedimentology. Academic Press, USA.

Shinn, E. A. 1991. Tidal flat environment. In Carbonate Depositional Environments (Scholle, P. A., Bebout, D. G. \& Moore, C. H., eds.), AAPG Memoir, 33, 171-210 (3rd printing).

Shogenova, A. 1989. Detailed subdivision of the Ordovician carbonate beds on the Rakvere Phosphorite Deposit by geophysical logging. Proc. Acad. Sci. Estonian SSR, 38, 10-13 (in Russian). 
Shogenova, A. 1998. Electrical properties of lower Paleozoic carbonate rocks and their relationships with porosity in Estonia. In Nordic Petroleum Technology Series: IV, Research in Petroleum Technology (Middleton, M., ed.), pp. 17-45. Nordisk Energi-Forskningsprogram Ås.

Shogenova, A. \& Puura, V. 1997. Petrophysical changes caused by dolomitization and leaching in fracture zones of lower Paleozoic carbonate rocks, North Estonia. In Nordic Petroleum Technology Series: I, Second Nordic Symposium on Petrophysics, Fractured Reservoirs (Middleton, M., ed.), pp. 155-185. Nordisk Energi-Forskningsprogram. Saghellinga, Norway.

Shogenova, A. \& Puura, V. 1998. Composition and petrophysical properties of Estonian Early Palaeozoic carbonate rocks. In Nordic Petroleum Technology Series: IV, Research in Petroleum Technology (Middleton, M., ed.), pp. 183-202. Nordisk Energi-Forskningsprogram Ås.

Shogenova, A., Bityukova, L. \& Götze, H.-J. 1998. Technique and results of complex analysis to study processes in sedimentary basin (in Estonia). Phys. Chem. Earth (Solar System), 23, 327-337.

Shogenova, A., Kirsimäe, K., Bityukova, L., Jõeleht, A. \& Mens, K. 2001. Physical properties and composition of cemented siliciclastic Cambrian rocks, Estonia. In Nordic Petroleum Technology Series: V, Research in Petroleum Technology (Fabricius, I., ed.), pp. 123-149. Nordisk Energi-Forskningsprogram Ås.

Shogenova, A., Mens, K., Sliaupa, S., Rasteniene, V., Jõeleht, A., Kirsimäe, K., Zabele, A. \& Freimanis, A. 2002. Factors influenced porosity of the siliciclastic rocks in the Baltic Cambrian basin. In 64th EAGE Conference and Technical Exhibition, Florence, 26-30 May 2002. Extended Abstracts, Vol. 2. European Association of Geoscientists \& Engineers, P218.

Shogenova, A., Jõeleht, A., Einasto, R., Kleesment, A., Mens, K. \& Vaher, R. 2003. Chemical composition and physical properties of rocks. In Ruhnu (500) Drill Core (Põldvere, A., ed.), Estonian Geol. Sections, 5, 34-39. Appendixes 4, 30, and 31on CD.

Šogenova, A., Einasto, R., Kleesment, A., Teedumäe, A. \& Jõeleht, A. 2003. Eesti Ordoviitsiumi, Siluri ja Devoni dolomiitsete kivimite koostise ja omaduste variatsioonid. In Eesti geoloogide neljas ülemaailmne kokkutulek. Eesti geoloogia uue sajandi künnisel. Konverentsi materjalid ja ekskursioonijuht (Plado, J. \& Puura, I., eds.), pp. 80-83. Sulemees, Tartu.

Teedumäe, A., Kiipli, T. \& Kallaste, T. 1999. Dolomites of the Muhu Formation (Silurian) in mainland Estonia: aspects of dolomitization, properties, and prospects of utilization. Proc. Estonian Acad. Sci. Geol., 48, 213-227.

Teedumäe, A., Kallaste, T. \& Kiipli, T. 2001. Aspects of dolomitization of the Mõhküla Beds (Silurian, Estonia). Proc. Estonian Acad. Sci. Geol., 50, 190-205.

Teedumäe, A., Kallaste, T. \& Kiipli, T. 2003. Comparative study of dolomites of different genesis (Raikküla Formation, Silurian, Estonia). Proc. Estonian Acad. Sci. Geol., 52, 113-127.

Teedumäe, A., Nestor, H. \& Kallaste, T. 2004. Sedimentary cyclicity and dolomitization of the Raikküla Formation in the Nurme drill core (Silurian, Estonia). Proc. Estonian Acad. Sci. Geol., 53, 42-62.

Tucker, M. E. \& Wright, V. P. 1994. Carbonate Sedimentology. Blackwell Scientific Publication.

Vingissaar, P., Oraspõld, A., Einasto, R. \& Jürgenson, E. 1965. Karbonaatkivimite ühtne klassifikatsioon ja legend. ENSV Teaduste Akadeemia Geoloogia Instituut, ENSV Geoloogia Valitsus, Tartu Riikliku Ülikooli geoloogiakateeder, Tallinn.

Warthmann, R., van Lith, Y., Vasconcelos, C., McKenzie, J. A. \& Karpoff, A. M. 2000. Bacterially induced dolomite precipitation in anoxic culture experiments. Geology, 28, 1091-1094.

Whittaker, S. G. \& Mountjou, E. W. 1996. Diagenesis of an Upper Devonian carbonate-evaporite sequence: Birdbear Formation, southern Interior Plains, Canada. J. Sedim. Res., 66, 965-975.

Wolf, K. H. \& Chilingarian, G. V. (eds.). 1994. Diagenesis, $I V$. Elsevier, Amsterdam.

Zenger, D. H. 1983. Burial dolomitization in the Lost Burro Formation (Devonian), east-central California, and the significance of late diagenetic dolomitization. Geology, 11, 519-522. 


\title{
Karbonaatsete ja karbonaatse tsemendiga kivimite litoloogia ja evolutsioon Eesti Devoni läbilõikes
}

\author{
Anne Kleesment ja Alla Shogenova
}

Põhiliselt terrigeensete kivimitega esindatud Eesti Devoni läbilõige sisaldab karbonaatsete ja karbonaat-terrigeensete kivimite vahekihte ja komplekse. Kuhjumise vältel toimus terrigeense ja karbonaatse materjali vahelduv settimine. Kõige rikkalikumalt esinevad peaaegu täielikult dolomiidistunud karbonaatkivimid Narva lademe profiilis. Uuritud 6 puursüdamiku (Ruhnu (500), Taagepera, Tartu (453), Valga (10), Võru ja Värska (6)) läbilõikes esinevad nii puhtad dolokivid, domeriidid kui ka karbonaat-terrigeensed segakivimid, mille kuhjumine toimus epikontinentaalses madalmeres, kus karbonaatse settimise ajal toimus purdkomponendi juurdevool. Karbonaat-terrigeensete kivimite rühma satuvad aga ka diageneesiprotsesside vältel dolomiitse tsemendi omandanud terrigeensed kivimid. Mineraloogiliste, petrograafiliste ja geokeemiliste andmete alusel võib eeldada, et läbilõikes esindatud dolokivid ja domeriidid settisid madalmere kaldalähedases piirkonnas, kus vesi oli Mg poolt küllastunud. Hilisemal diageneesil allusid kivimid tähelepanuväärsetele muutustele. Tihenemise ja dolomiidistumise käigus toimus poorsuse muutus. Viimane on otseses positiivses sõltuvuses savikomponendi sisaldusest. Terrigeensete kivimite tsementatsioon toimus $\mathrm{Mg}$ ja $\mathrm{Mn}$ poolt rikastunud lahuste kaasmõjul diageneesi keskmises ja hilises staadiumis. Kagu-Eesti piirkonnas toimus mõnel tasemel ka kipstsemendi teke ja dolomiitse tsemendi asendumine kaltsiidiga hilise diageneesi etapil. Sedimentatsioon ja diageneesi käik peegelduvad karotaažikõveratel. 